A

\title{
FINANSOWANIE ZWIĄZKÓW WYZNANIOWYCH W REPUBLICE WŁOSKIEJ: ZARZĄDZANIE ŚRODKAMI Z ASYGNATY PODATKOWEJ (OTTO PER MILLE) PRZEDMIOTEM KRYTYKI TRYBUNAŁU OBRACHUNKOWEGO
}

\author{
Streszczenie
}

Opracowanie koncentruje się na jednym z najważniejszych elementów systemu finansowania kościołów i innych związków wyznaniowych we Włoszech, jakim jest asygnata podatkowa w wysokości $0,8 \%$ podatku dochodowego od osób fizycznych (tzw. otto per mille). Włoski Trybunał Obrachunkowy (Corte dei Conti) w latach 2014-2018 przyjął cztery uchwały dotyczące tej problematyki. Zatwierdzone na ich podstawie raporty zawierają szereg uwag dotyczących sposobu zarządzania środkami pochodzącymi z tego źródła. W pierwszej części opracowania scharakteryzowana została instytucja otto per mille, będąca punktem odniesienia w wielu dyskusjach dotyczących nowoczesnych metod finansowania związków wyznaniowych. Następnie szczegółowo przedstawiono zarzuty podniesione w raportach oraz oficjalne stanowiska, jakie w ich sprawie sformułowały związki wyznaniowe, w tym Kościół Katolicki. W podsumowaniu opracowania sformułowano uwagi końcowe, stanowiące próbę krytycznego spojrzenia zarówno na opinie wyrażone przez włoski Trybunał Obrachunkowy, jak i na odnoszące się do nich komentarze i związane z nimi inicjatywy.

Słowa kluczowe: asygnata podatkowa; otto per mille; Włochy; kościoły i inne związki wyznaniowe; podatnik; podatek dochodowy od osób fizycznych

$$
* * * * *
$$

* Ks. dr hab., prof. KUL, Katedra Prawa Wyznaniowego, Wydział Prawa, Prawa Kanonicznego i Administracji, Katolicki Uniwersytet Lubelski Jana Pawła II, Al. Racławickie 14, 20-950 Lublin, e-mail: pstan@kul.pl. ORCID 0000-0002-2437-8513.

** Dr, Katedra Prawa Wyznaniowego, Wydział Prawa, Prawa Kanonicznego i Administracji, Katolicki Uniwersytet Lubelski Jana Pawła II, Al. Racławickie 14, 20-950 Lublin, e-mail: mordon@kul.pl. ORCID 0000-0003-0908-0628. 


\section{WPROWADZENIE}

W dyskusjach dotyczących finansowania kościołów i innych związków wyznaniowych we Włoszech szczególne miejsce w ostatnich latach zajmuje krytyka sformułowana przez włoski Trybunał Obrachunkowy w stosunku do asygnaty podatkowej określanej powszechnie - od jej wysokości - jako otto per mille (0,8\%). W okresie 2014-2018 Trybunał przyjął aż cztery uchwały odnoszące się do tej problematyki (i nie jest wcale pewne, że do tej kwestii nie będzie powracał w przyszłości). W zatwierdzonych na podstawie tych uchwał raportach zawarto surowe oceny dotyczące sposobu zarządzania środkami pochodzącymi z tego źródła (które to środki, na podstawie obowiązujących przepisów, są rozdzielane zgodnie z wolą podatników pomiędzy korzystające $\mathrm{z}$ tego rozwiązania związki wyznaniowe oraz państwo). Do zwrócenia uwagi na sformułowaną w tym trybie krytykę skłania przede wszystkim fakt, że odnosi się ona do rozwiązań traktowanych niejednokrotnie jako ważny punkt odniesienia w dyskusjach, których przedmiotem są nowoczesne metody finansowania związków wyznaniowych ${ }^{1}$. Jej znajomość może się ponadto przyczynić do lepszego rozumienia dynamiki współczesnych relacji Państwo - Kościół.

Trybunał Obrachunkowy (Corte dei conti) jest we Włoszech konstytucyjnym organem kontroli państwowej. Zgodnie z Konstytucją Republiki Włoskiej z dnia 27 grudnia 1947 r. ${ }^{2}$ wykonuje on ,wstępną kontrolę legalności aktów rządu oraz kontrolę następczą w zakresie realizacji budżetu państwa. Uczestniczy, w przypadkach i w formach określonych przez ustawę, w kontroli zarządzania finansowego instytucji dotowanych regularnie przez państwo w trybie zwykłym. Wynik dokonanej kontroli przedstawia bezpośrednio izbom parlamentu" (art. 100 ust. 2) ${ }^{3}$.

Kompetencje Trybunału Obrachunkowego zostały uszczegółowione w ustawie z dnia 14 stycznia 1994 r. (nr 20) $)^{4}$ Sprecyzowano, że do jego

1 Zob. np. Krukowski 2013; Stanisz 2009.

2 Konstytucja Republiki Włoskiej (Costituzione della Repubblica Italiana) z dnia 22 grudnia 1947 r., ,Gazzetta Ufficiale della Repubblica Italiana” (dalej: G. U.) nr 298 z 27 grudnia 1947 r. (ze zm.).

3 Tłumaczenie za: Witkowski 2004.

4 Ustawa z dnia 14 stycznia 1994 r. (nr 20). Disposizioni in materia di giurisdizione e controllo della Corte dei Conti, G. U. nr 10 z 14 stycznia 1994 r. (ze zm.). 
zadań należy m.in. kontrolowanie zgodności rezultatów działalności administracyjnej z celami określonymi w ustawach, z uwzględnieniem oceny kosztów, sposobów oraz czasu realizacji określonych działań (art. 3 ust. 4). Zgodnie z ustawą organy administracji publicznej, których dotyczy raport przyjęty przez Trybunał, są zobowiązane do przekazania mu (a nadto również Parlamentowi) w ciągu sześciu miesięcy informacji na temat działań podjętych $\mathrm{w}$ związku $\mathrm{z}$ treścią tego raportu (art. 3 ust. 6). Jeśli natomiast zainteresowane organy nie uznają zasadności zarzutów sformułowanych przez Trybunał i nie zamierzają podejmować działań zmierzających do ich uwzględnienia, zobowiązane są - w ciągu trzydziestu dni - do przekazania umotywowanej informacji na ten temat nie tylko samemu Trybunałowi, ale też prezydiom obu izb Parlamentu i Rady Ministrów 5 .

Pierwsza z uchwał stanowiących przedmiot niniejszego opracowania została przyjęta w dniu 23 października 2014 r. Opublikowano ją 19 listopada 2014 r. ${ }^{6} \mathrm{Na}$ jej podstawie przyjęto raport wskazujący nieprawidłowości ujawnione $\mathrm{w}$ trakcie postępowania kontrolnego dotyczącego gospodarowania środkami uzyskiwanymi w ramach $0,8 \%$ podatku dochodowego od osób fizycznych. Zdecydowana większość ze sformułowanych wówczas zarzutów była powtarzana również w kolejnych raportach, z których pierwszy przyjęto w dniu 1 października 2015 r., publikując go 26 października 2015 r. ${ }^{7}$ Przedmiotem zatwierdzonego w tym trybie raportu były nieliczne środki zaradcze podjęte przez zainteresowane władze publiczne wobec ustalonych nieprawidłowości. Do tej samej kwestii powrócono po upływie kolejnego roku. Uchwałą podjętą na posiedzeniu w dniu 20 listopada 2016 r., którą opublikowano 23 grudnia 2016 r. $^{8}$, przyjęto bowiem raport relacjonujący i oceniający działania podjęte przez organy administracji publicznej w konsekwencji wcześniejszych interwencji

5 Obowiązek ten został sformułowany w art. 3 ust. 64 ustawy z dnia 24 grudnia 2007 r. (nr 244). Disposizioni per la formazione del bilancio annuale e pluriennale dello Stato (legge finanziaria 2008), G. U. nr 300 z 28 grudnia 2007 r. - Supplemento Ordinario (ze zm.).

6 Deliberazione n. 16/2014/G. Destinazione e gestione dell'8 per mille dell'Irpef.

7 Deliberazione n. 8/2015/G. Destinazione e gestione dell'8 per mille dell'Irpef: le misure conseguenziali finalizzate alla rimozione delle disfunzioni rilevate.

8 Deliberazione n. 16/2016/G. Destinazione e gestione dell'8 per mille dell'Irpef: le azioni intraprese a seguito delle deliberazioni della Corte dei conti. 
Trybunału. Kwestie dotyczące omawianej asygnaty podatkowej zostały wreszcie podjęte również w uchwale Trybunału Obrachunkowego z dnia 4 październiku 2018 r., którą opublikowano 29 października 2018 r. ${ }^{9}$ Tym razem odniesiono się do wyników kontroli działalności centrów poradnictwa podatkowego (Centri di assistenza fiscale - Caf) jako pośredników w procedurach dotyczących wskazywania podmiotów, które mają być destynatariuszami środków pochodzących z $0,8 \%$ podatku dochodowego od osób fizycznych (a także z $0,5 \%$ tego podatku - cinque per mille - które mogą być przekazane na organizacje non profit). Kontrola ta została przeprowadzona przez Agencję Dochodów (Agenzia delle Entrate) w konsekwencji krytyki sformułowanej przez Trybunał w poprzednich latach. W przyjętym raporcie po raz kolejny zwrócono uwagę również na wytykane wcześniej nieprawidłowości, odnosząc się przy tym do nielicznych inicjatyw podjętych przez władze publiczne w odpowiedzi na krytyczne stanowisko Trybunału.

Zgodnie z opinią wyrażoną przez Trybunał Obrachunkowy we wskazanych wyżej raportach, na krytykę zasługują nie tylko różnorodne rozwiązania przyjęte w praktyce stosowania przepisów dotyczących omawianej asygnaty podatkowej, ale i treść niektórych dotyczących jej przepisów. Zastrzeżenia zgłoszono przede wszystkim do unormowania, zgodnie z którym całość środków z otto per mille jest dzielona z uwzględnieniem woli tylko tych podatników, którzy zdecydowali się na wyraźne wskazanie wybranego przez nich destynatariusza. Zdaniem Trybunału jest to równoznaczne z ignorowaniem stanowiska tych podatników, którzy powstrzymali się od skorzystania z przysługującego im w tym zakresie prawa. Negatywnie oceniono też stały wzrost wielkości środków uzyskiwanych z omawianej asygnaty podatkowej przez związki wyznaniowe (a zwłaszcza przez Kościół Katolicki). Zwrócono przy tym uwagę na brak jakiejkolwiek reakcji właściwych władz publicznych na to zjawisko. Bardzo surowo odniesiono się do praktyki przyjętej przy wydatkowaniu kwot z asygnaty podatkowej przez państwo,

9 Zob. Deliberazione n. 24/2018/G. La scelta dell'8 per mille dell'Irpef da parte dei contribuenti e l'audit dell'Agenzia delle entrate sui comportamenti degli intermediari; http://www.corteconti.it/export/sites/portalecdc/_documenti/controllo/sez_centrale_controllo_amm_stato/2018/delibera_24_2018_g.pdf [dostęp: 5.01.2019]. Wszystkie poprzednie uchwały zostały opublikowane m.in. w formie załączników do uchwały z 2018 r. 
której skutkiem jest stałe zmniejszanie się liczby podatników decydujących się na wybór tego właśnie destynatariusza środków pochodzących z $0,8 \%$ podatku dochodowego od osób fizycznych. Zwrócono ponadto uwagę na brak jednolitości statusu prawnego wszystkich związków wyznaniowych na gruncie przepisów regulujących omawianą instytucję prawną. Krytycznie odniesiono się również do niektórych praktyk dostrzeżonych w trakcie kontroli działalności centrów poradnictwa podatkowego, mających związek z udziałem podatników w decydowaniu o podziale środków z otto per mille. Szczegółowe zrelacjonowanie wymienionych zarzutów będzie przedmiotem kolejnych części niniejszego opracowania. Uprzednio zostanie scharakteryzowana instytucja prawna, której funkcjonowanie stało się przedmiotem interwencji Trybunału. Natomiast po zrelacjonowaniu stanowiska Trybunału zostaną przedstawione oficjalne stanowiska, jakie w omawianej sprawie zajęli przedstawiciele Kościoła Katolickiego i niektórych innych związków wyznaniowych, a także konsekwencje omawianych raportów. Całość zamkną uwagi końcowe stanowiące próbę krytycznego spojrzenia zarówno na opinie wyrażone przez włoski Trybunał Obrachunkowy, jak i na odnoszące się do niej komentarze i związane z nimi inicjatywy.

\section{PRZEDMIOT KONTROLI}

Przedmiotem omawianej kontroli uczyniono sposób zarządzania środkami pochodzącymi z asygnaty podatkowej, stanowiącej we Włoszech najważniejszy element systemu finansowania związków wyznaniowych. Jak wynika z informacji opublikowanych na stronie Departamentu Finansów (Dipartimento delle Finanze) włoskiego Ministerstwa Ekonomii i Finansów (Ministero dell'Economia e delle Finanze), w ramach podziału 0,8\% podatku dochodowego od osób fizycznych w 2018 r. rozdzielono wyraźnie ponad miliard (1.230.348.167) euro, z której to sumy państwu przypadło jedynie ok. 14\% (175.632.294 euro $)^{10}$.

10 Zob. Ripartizione del gettito derivante dall'otto per mille dell'Irpef, http://www1. finanze.gov.it/finanze3/stat_8xMilleSerie/index.php?req_classe=01 [dostęp: 20.12.2018]. Zob. także dane zamieszczone w załączniku A do artykułu. 
Istota instytucji określanej jako otto per mille polega na przyznaniu podatnikom prawa bezpośredniego udziału w podejmowaniu decyzji o podziale środków składających się na $0,8 \%$ podatku dochodowego od osób fizycznych pomiędzy uprawnione związki wyznaniowe oraz państwo. Rozwiązanie to - zastosowane do Kościoła Katolickiego - zostało wprowadzone do prawa włoskiego na podstawie dwóch ustaw z dnia 20 maja 1985 r. (nr 206 i nr 222) ${ }^{11}$, których treść została zdeterminowana przez ustalenia państwowo-kościelnej komisji parytetowej, ustanowionej zgodnie z włoskim Konkordatem z 1984 r. (art. 7 ust. 6) ${ }^{12}$. W następnych latach prawo do udziału w podziale środków pochodzących z $0,8 \%$ podatku dochodowego od osób fizycznych, na mocy ustaw uchwalanych w trybie art. 8 ust. 3 włoskiej ustawy zasadniczej, było stopniowo rozszerzane na niekatolickie związki wyznaniowe. W konsekwencji tego procesu, w podziale środków z otto per mille, obok państwa oraz Kościoła Katolickiego, uczestniczą dziś również: Zgromadzenia Boże we Włoszech (Assemblee di Dio in Italia), Włoska Unia Chrześcijańskich Kościołów Adwentystów Dnia Siódmego (Unione Italiana delle Chiese Cristiane Avventiste del $7^{\circ}$ Giorno), Stół Waldensów (Tavola Valdese), Kościół Ewangelicko-Luterański we Włoszech (Chiesa Evangelica Luterana in Italia), Związek Włoskich Gmin Żydowskich (Unione delle Comunità Ebraiche Italiane), Chrześcijańska Unia Ewangelicko-Baptystyczna Włoch (Unione Cristiana Evangelica Battista d'Italia), Święta Archidiecezja Prawosławna Włoch i Egzarchat dla Europy Północnej

11 Zob. ustawę z dnia 20 maja 1985 r. (nr 206). Ratifica ed esecuzione del protocollo, firmato a Roma il 15 novembre 1984, che approva le norme per la disciplina della materia degli enti e beni ecclesiastici formulate dalla commissione paritetica istituita dall'articolo 7 , n. 6, dell'accordo, con protocollo addizionale, del 18 febbraio 1984 che ha apportato modificazioni al Concordato lateranense del 1929 tra lo Stato italiano e la Santa Sede (G. U. nr 123 z 27 maja 1985 r. - Supplemento Ordinario) oraz ustawę z dnia 20 maja 1985 r. (nr 222). Disposizioni sugli enti e beni ecclesiastici in Italia e per il sostentamento del clero cattolico in servizio nelle diocesi (G. U. nr 129 z 3 czerwca 1985 r. - Supplemento Ordinario). Nieracjonalność przyjęcia dwóch aktów normatywnych mających analogiczną treść zasadnie krytykuje Finocchiaro 2015, 13-14.

12 Zob. ustawę z dnia 25 marca 1985 r. (nr 121). Ratifica ed esecuzione dell'accordo, con protocollo addizionale, firmato a Roma il 18 febbraio 1984, che apporta modificazioni al Concordato lateranense dell'11 febbraio 1929, tra la Repubblica italiana e la Santa Sede (G. U. nr 85 z 10 kwietnia 1985 r. - Supplemento Ordinario). 
(Sacra Arcidiocesi ortodossa d'Italia ed Esarcato per l'Europa Meridionale), Kościół Apostolski we Włoszech (Chiesa Apostolica in Italia), Włoska Unia Buddyjska (Unione Buddhista Italiana), Włoska Unia Hinduistyczna Sanatana Dharma Samgha (Unione Induista Italiana Sanatana Dharma Samgha) oraz Włoski Instytut Buddyjski Soka Gakkai (Istituto Buddista Italiano Soka Gakkai) ${ }^{13}$.

Wyjaśniając istotę omawianej instytucji prawnej, należy zwrócić uwagę, że włoski podatnik - w przeciwieństwie np. do polskiego podatnika dokonującego wpłat $1 \%$ na rzecz organizacji pożytku publicznego - nie decyduje o przeznaczeniu części swojego podatku. Podejmując decyzję o wskazaniu wybranego związku wyznaniowego lub państwa, uczestniczy raczej w procedurach mających na celu określenie proporcji, według których dzielona jest corocznie całość środków stanowiących $0,8 \%$ podatku dochodowego od osób fizycznych. Podjęta przez niego decyzja jest więc traktowana na podobieństwo głosu oddanego w referendum lub wyborach. Wiąże się to z dwiema kolejnymi cechami rozwiązań składających się na instytucję otto per mille. Po pierwsze, państwo jako potencjalny destynatariusz środków składających się na tę część podatku konkuruje o nie na równych zasadach ze związkami wyznaniowymi. Jest ono bowiem po prostu jednym z dwunastu podmiotów, z których każdy - bez żadnej różnicy - może zostać wskazany przez podatników. Istotne jest przy tym również to, że środki pochodzące z omawianego źródła mogą być przez państwo (podobnie jak przez związki wyznaniowe) wydatkowane jedynie na ściśle określone cele, których katalogi określono w ustawach. Po drugie zaś, proporcje wynikające z decyzji podatników, którzy skorzystali z przysługującego im prawa wskazania destynatariusza, są stosowane do całości wpływów z $0,8 \%$ podatku dochodowego od osób fizycznych. Mają więc zastosowane również do podziału tej ich części, którą można byłoby przypisać podatnikom powstrzymującym się od czynnego udziału w podejmo-

13 Spośród związków wyznaniowych, których sytuacja prawna została uregulowana w ustawie opartej na porozumieniu zawartym uprzednio przez Radę Ministrów z ich właściwymi przedstawicielstwami, jedynie Kościół Jezusa Chrystusa Świętych Dni Ostatnich (Chiesa di Gesù Cristo dei Santi degli Ultimi Giorni) odrzucił możliwość korzystania ze środków pochodzących z asygnaty podatkowej. Zob. Elefante 2018, 88. 
waniu decyzji o przeznaczeniu środków z otto per mille (tzw. „wybory niewyrażone" - scelte non espresse $)^{14}$.

\section{KWESTIA UWZGLĘDNIANIA TZW. „WYBORÓW NIEWYRAŻONYCH”}

Przedmiotem negatywnej opinii Trybunału stało się przede wszystkim rozwiązanie dotyczące tzw. „wyborów niewyrażonych”. Treści odnoszące się do tej problematyki wysunięto na pierwszy plan w raporcie z 2014 r., konsekwentnie wracając do nich również w kolejnych raportach.

Istotę stanowiska zajętego przez Trybunał w omawianej kwestii oddają zdania otwierające pierwszą z merytorycznych części raportu z 2014 r. Stwierdzono tam: „Wpłata $0,8 \%$ jest obowiązkowa dla wszystkich, bez względu na wyrażoną intencję; jednak podział wpływów z tego ułamka podatku dochodowego od osób fizycznych zależy jedynie od części podatników: od dokonujących wyboru. Mechanizm ten neutralizuje fakt niedokonania wyboru. W ten sposób każdy, niezależnie od swej woli, jest zaangażowany w finansowanie wyznań, z wyraźną dla nich korzyścią, ponieważ tylko dokonujący wyboru decydują za wszystkich, co ma tę dalszą konsekwencję, że rzeczywiste znaczenie pojedynczego wyboru jest odwrotnie proporcjonalne do liczby tych, którzy wyrażają swą wolę"15.

Uzasadniając krytykę rozdzielania środków pochodzących z $0,8 \%$ podatku dochodowego od osób fizycznych z uwzględnieniem tzw. „wy-

14 Zgromadzenia Boże we Włoszech oraz Kościół Apostolski we Włoszech, w konsekwencji decyzji podjętych przez ich przedstawicieli, uczestniczą jedynie w podziale środków, o których przeznaczeniu podatnicy zdecydowali w sposób wyraźny. Kwoty, które mogłyby im przypaść w konsekwencji tzw. wyborów niewyrażonych, trafiają więc z ich woli do państwa. Zob. Elefante 2018, 88-89. Włoską asygnatę podatkową na rzecz związków wyznaniowych charakteryzują ponadto: Astorri 2009; Misztal, Stanisz 2009; Ferrari 2007, 399-402; Vegas 2004; Feliciani 2000, 45-64.

15 Il contributo dell'8 per mille è obbligatorio per tutti, a prescindere dall'intenzione manifestata; tuttavia, l'allocazione di questa quota del gettito Irpef è determinata da una sola parte dei contribuenti: gli optanti. Infatti, il meccanismo neutralizza la non scelta. In tal modo, ognuno è coinvolto, indipendentemente dalla propria volontà, nel finanziamento delle confessioni, con evidente vantaggio per le stesse, dal momento che i soli optanti decidono per tutti, con l'uteriore conseguenza che il peso effettivo di una singola scelta è inversamente proporzionale al numero di chi si esprime. Raport z 2014 r., s. 17. 
borów niewyrażonych", Trybunał za własną przyjął opinię, której autorem jest Carlo Cardia ${ }^{16}$. Jej istotą jest twierdzenie, że decyzja o rezygnacji z prawa wskazania preferowanego destynatariusza omawianej części wpływów podatkowych powinna być interpretowana jako manifestacja krytycznej postawy podatnika wobec instytucji określanej jako otto per mille, a przynajmniej jako znak woli zdystansowania się od tej instytucji prawnej. W związku z tym - jak stwierdzono - sumy odpowiadające tej części wpływów, co do której podatnicy nie wyrazili swej woli, powinny pozostać w dyspozycji państwa i być traktowane tak jak środki publiczne in genere, lub co najmniej jako środki państwowe przeznaczone na cele charytatywne i humanitarne $\mathrm{e}^{17}$.

Na szczególną krytykę zasługuje - zdaniem Trybunału Obrachunkowego - ignorowanie woli podatników, którzy niepoprawnie wypełnili deklarację w części dotyczącej przeznaczenia wpływów z otto per mille. Pomimo tego, że okazali wolę wzięcia udziału w podejmowaniu decyzji o przeznaczeniu tych środków, traktuje się ich tak, jakby zrezygnowali z przysługującego im prawa. Przypisywana im część omawianych wpływów podatkowych dzielona jest bowiem z uwzględnieniem decyzji podjętych jedynie przez tych, którzy swą wolę wyrazili w sposób formalnie poprawny. Zastrzeżenia zgłoszono również do rozwiązania polegającego na włączeniu do kwoty podlegającej takiemu podziałowi środków wpłaconych na zasadzie zaliczek podatkowych przez osoby zmarłe w trakcie roku podatkowego ${ }^{18}$.

Krytyczną wymowę opinii Trybunału w omawianej kwestii potęgują odniesienia do stanu faktycznego. Jest bowiem faktem, że podatnicy korzystający z prawa udziału w czynnym decydowaniu o podziale funduszy składających się na $0,8 \%$ podatku dochodowego od osób fizycznych stanowią mniejszość w ogólnej liczbie podatników. Jak podkreślono, na zasadzie tzw. „wyborów niewyrażonych” dzielona jest więc większość tych wpływów. Odsetek podatników, którzy korzystają z prawa wskazania destynatariusza środków pochodzących z otto per mille, od 1993 r. w istocie nigdy nie przekroczył 46,1\% (w latach 1998-2003 nie przekraczając

\footnotetext{
16 Zob. Cardia 1992, 278-279.

17 Raport z 2014 r., s. 13.

18 Tamże.
} 
nawet 40\%; natomiast w latach 2004-2012 sytuując się w przedziale 40\%46,1\%). W konsekwencji, jak to ujęto, w niektórych latach zastosowanie przyjętego rozwiązania doprowadziło niemal do potrojenia środków trafiających do poszczególnych beneficjentów (twierdzenie to dotyczyło zapewne 1998 r., kiedy „współczynnik multiplikacyjny” był najwyższy w historii i przekroczył 265\%), uprzywilejowując przede wszystkim tych, którzy i tak uzyskują największe kwoty (a więc na pierwszym miejscu Kościół Katolicki). Rezygnacja z omawianego rozwiązania przyniosłaby natomiast dla budżetu państwa oszczędności rzędu $600 \mathrm{mln}$ euro ${ }^{19}$.

$\mathrm{Z}$ dezaprobatą stwierdzono wreszcie, że ,brakuje informacji na temat tego szczególnego sposobu rozdzielania środków. W związku z tym obywatele, nawet jeśli odznaczają się zwykłą starannością, mogą być przekonani, że skutek w postaci przyznania środków następuje jedynie w konsekwencji dokonania wyraźnego wyboru" ${ }^{20}$. W tym kontekście negatywnie oceniono również fakt, że dopiero od 2006 r. w formularzach właściwych deklaracji podatkowych - choć jedynie z użyciem małej czcionki - umieszczana jest informacja o sposobie dzielenia wpływów z otto per mille ${ }^{21}$.

Krytykując fakt uwzględniania przy rozdzielaniu środków składających się na wpływy z 0,8\% podatku dochodowego od osób fizycznych tzw. „wyborów niewyrażonych”, zwrócono ponadto uwagę, że rozwiązanie to różni się od tego, które jest stosowane w przypadku asygnaty podatkowej na rzecz organizacji pożytku publicznego $(0,5 \%$ - cinque per mille). Chociaż obie instytucje służą promocji udziału podatników w podejmowaniu decyzji o finansowaniu działalności uznawanej za użyteczną społecznie i realizowaną przez podmioty niepubliczne, to jednak istniejące pomiędzy nimi różnice nie ograniczają się do odmiennej wysokości asygnaty i dotyczą w szczególności przeznaczenia środków, co do których podatnicy nie określili swej woli w sposób wyraźny. W przypadku instytucji cinque per mille brak wyraźnej decyzji podatnika, odnoszącej się zresztą precyzyj-

19 Tamże, s. 14-17.

20 Assente risulta essere l'informazione su tale peculiare modalità di attribuzione. I cittadini - anche dotati di diligenza media - possono essere indotti, pertanto, a ritenere che solo con una scelta esplicita i fondi vengano assegnati. Tamże, s. 13-14.

${ }_{21}$ Tamże, s. 14. W raporcie z 2015 r. odnotowano informację pochodzącą od Agencji Dochodów o zwiększeniu czcionki, z wykorzystaniem której w formularzach podatkowych informuje się o zasadach rozdzielania środków pochodzących z omawianej asygnaty (s. 19). 
nie do części płaconego przez niego podatku, skutkuje włączeniem tych środków do budżetu państwa. Jak stwierdzono, rozwiązania stosowane w odniesieniu do organizacji pożytku publicznego nie tylko w mniejszym stopniu uszczuplają dochody budżetu państwa, ale też wyraźniej szanują wolę podatników i zasadę proporcjonalności. Charakteryzują się też dużo bardziej inkluzywnym charakterem, ponieważ o włączeniu kolejnych podmiotów do systemu decyduje jedynie spełnienie warunków określonych przez przepisy, a nie konieczność zawarcia trudnego do osiągnięcia porozumienia z rządem. Zwrócono ponadto uwagę, że od instytucji otto per mille różni się również ostatnio wprowadzona asygnata podatkowa na rzecz partii politycznych $(0,2 \% \text { podatku dochodowego od osób fizycznych })^{22}$.

\section{WIELKOŚĆ I SPOSÓB WYDATKOWANIA ŚRODKÓW UZYSKIWANYCH PRZEZ ZWIĄZKI WYZNANIOWE}

Jak wynika z analizowanych raportów, jedną z podstawowych przyczyn zainteresowania Trybunału Obrachunkowego instytucją otto per mille była wielkość środków trafiających z tego źródła do Kościoła Katolickiego. Dzięki obowiązującym rozwiązaniom Konferencja Episkopatu Włoch od ponad dekady otrzymuje bowiem corocznie do rozdysponowania sumy przekraczające miliard euro lub przynajmniej do tej kwoty zbliżone (np. w 2014 r. było to 1.054 .310 .702 euro, natomiast w 2018 r. 997.726 .597 euro $)^{23}$. W raporcie z 2014 r. zwrócono uwagę, że dochody uzyskiwane przez Kościół Katolicki z 0,8\% podatku dochodowego od osób fizycznych w ciągu ostatniego ćwierćwiecza wzrosły pięciokrotnie, a ich wielkość nie znajduje dziś odpowiedników w innych państwach przyjmujących podobne rozwiązania. W tym kontekście przypomniano, że jednym z zadań komisji parytetowej, o której mowa w art. 49 ustawy nr 222 z 1985 r., jest ocena wielkości wpływów uzyskiwanych przez Kościół $\mathrm{z}$ asygnaty podatkowej, dokonywana w celu rozważenia potrzeby modyfikacji jej wysokości. Systematyczne zwiększanie się kwot pochodzą-

22 Raport z 2014 r., s. 73-74.

23 Zob. Otto per mille. Scelte e importi erogati; http://www1.finanze.gov.it/finanze2/ pagina_dichiarazioni/ottoxmille.php\#navigazione_dinamica [dostęp: 21.12.2018]. 
cych z otto per mille przez długi czas nie skutkowało jednak podjęciem przez komisję żadnych inicjatyw, których celem miałoby być wywołanie refleksji nad potrzebą dokonania jakichkolwiek zmian. Jak odnotowuje się w raporcie z 2018 r., dopiero w październiku 2016 r., wyraźnie pod wpływem krytyki sformułowanej przez Trybunał Obrachunkowy, przedstawiciele rządu w komisji parytetowej, powołanej zgodnie z ustawą nr 222 z 1985 r., wystąpili z postulatem, aby przy okazji kolejnej oceny funkcjonowania systemu (dotyczącej lat 2014-2016) przedyskutować również kwestię potrzeby ewentualnej zmiany wysokości omawianej asygnaty (zasadnie zauważono przy tym jednak, że analogiczne dyskusje należy przeprowadzić podczas posiedzeń komisji oceniających funkcjonowanie asygnaty podatkowej w odniesieniu do niekatolickich związków wyznaniowych, a warunkiem efektywności prac nad dokonaniem zmian jest przyjęcie przez Radę Ministrów precyzyjnych wytycznych dla przedstawicieli rządu w tych komisjach, których to wytycznych - jak dotąd - nie sformułowano ${ }^{24}$. Tymczasem już w 1996 r. ta sama komisja sygnalizowała, że dalszy wzrost wielkości środków przypadających Kościołowi Katolickiemu dzięki decyzjom podatników będzie musiał zaowocować postulatami dokonania zmian, a na rodzące się w związku z tym wątpliwości od lat zwracał uwagę jeden z członków tejże komisji (C. Cardia) ${ }^{25}$. W swoich publikacjach wyrażał on wręcz opinię, że wielkość środków uzyskiwanych przez Kościół Katolicki z asygnaty podatkowej nie tylko znacząco przekracza potrzeby wyznaczone przez konieczność godnego utrzymania duchownych, ale wręcz prowadzi do nieracjonalnego wydatkowania środków publicznych i pozostaje w coraz większym napięciu z zasadą świeckości państwa ${ }^{26}$. Również w opinii Trybunału nie ma dziś żadnego uzasadnienia dla dalszego odkładania decyzji o zmianie wielkości państwowego zaangażowania w finansowanie Kościoła Katolickiego ${ }^{27}$.

Dodatkowo uzasadniając postawioną wyżej tezę, w raporcie z 2014 r. zwrócono uwagę, że zwiększanie się wielkości środków przypadających Kościołowi Katolickiemu i innym związkom wyznaniowym w konse-

24 Raport z 2018 r., s. 25-26.

25 Raport z 2014 r., s. 24-25.

26 Zob. np. Cardia 2001, 174.

27 Raport z 2014 r., s. 25-26. 
kwencji obowiązujących rozwiązań prawnopodatkowych nie jest wyłącznie skutkiem decyzji podejmowanych przez podatników. Istotne znaczenie posiada bowiem generalny wzrost wpływów z tej daniny, będący m.in. konsekwencją narastającej presji podatkowej. Wskaźnik tego wzrostu za lata 1990-2011 wyniósł bowiem 179\%, znacząco przewyższając zarówno wskaźnik wzrostu PRB (126\%), jak i wskaźnik inflacji (84\%) ${ }^{28}$. Jak przy tym stwierdzono, kwoty przeznaczane przez państwo na działalność związków wyznaniowych w konsekwencji wykorzystywania instytucji otto per mille stanowią jedyną pozycję budżetową, która w okresie przedłużającego się kryzysu ekonomicznego nie została dotknięta żadnymi redukcjami. W opinii Trybunału wielkość środków uzyskiwanych przez związki wyznaniowe z tego źródła musi być zresztą oceniana z uwzględnieniem wszystkich innych sposobów finansowego zaangażowania państwa na cele związane z działalnością podmiotów konfesyjnych. Tymczasem mechanizmów skutkujących finansowaniem celów wyznaniowych z funduszy publicznych jest wiele. Wyliczono wśród nich: dotacje udzielane szkołom prowadzonym przez instytucje wyznaniowe oraz oratoriom, wynagrodzenia wypłacane nauczycielom religii oraz kapelanom w instytucjach publicznych, dotacje na konstrukcję i utrzymanie budynków służących kultowi, korzystanie przez podmioty wyznaniowe z $0,5 \%$ podatku dochodowego od osób fizycznych na rzecz organizacji pożytku publicznego, a także publiczne dotacje na organizację imprez o charakterze religijnym. Zwrócono też uwagę na rozwiązania, które powinny być postrzegane w kategoriach pośredniego finansowania związków wyznaniowych z funduszy publicznych, wskazując na pomniejszanie podstawy opodatkowania dochodów osób fizycznych o kwoty darowizn składanych przez podatników na cele religijne oraz zwolnienia obowiązujące na gruncie podatku od nieruchomości. Jak stwierdzono, jednoczesne obowiązywanie wszystkich wskazanych rozwiązań prowadzi niejednokrotnie do sytuacji „nakładania się” różnych możliwości uzyskania dotacji na te same cele. Z tego właśnie powodu w ustawie z 11 marca 2014 r. (nr 23) ${ }^{29}$, w której generalnie wezwano rząd do racjonalizacji systemu podatkowego z wykorzystaniem rozporządzeń ustawo-

28 Raport z 2014 r., s. 6.

29 Ustawa z dnia 11 marca 2014 r., nr 23. Delega al Governo recante disposizioni per un sistema fiscale più equo, trasparente e orientato alla crescità, G. U. nr 59 z 12 marca 2014 r. 
dawczych (decreti legislativi), uwzględniono również kwestie dotyczące omawianej asygnaty podatkowej. Zobligowano mianowicie rząd do tego, aby zracjonalizował wydatki ponoszone w związku z obowiązywaniem tej instytucji prawnej (zob. art. 4 ust. 2 in fine) ${ }^{30}$.

Uwagę Trybunału Obrachunkowego zwrócił również sposób wydatkowania środków uzyskiwanych przez związki wyznaniowe z $0,8 \%$ podatku dochodowego od osób fizycznych. Zauważono przede wszystkim niejednolitość w zakresie ich wykorzystywania na działalność charytatywną. O ile bowiem Kościoły reprezentowane przez Stół Waldensów oraz Kościoły Adwentystów Dnia Siódmego przeznaczają na ten cel niemal całość wpływów uzyskiwanych z otto per mille, o tyle Kościół Ewangelicko-Luterański i Kościół Katolicki wydają na działalność charytatywną mniejszość środków uzyskiwanych z tego źródła (odpowiednio: ok. 33\% i ok. 20\%), koncentrując się przede wszystkim na potrzebach kultu i działalności duszpasterskiej (ok. 40\% w obu przypadkach) oraz na utrzymaniu duchownych (ok. 20\% w przypadku Kościoła Ewangelicko-Luterańskiego i ok. 37\% w przypadku Kościoła Katolickiego) ${ }^{31}$. Jak spostrzeżono w raporcie z 2014 r., kwestia stosunkowo małego udziału kwot przeznaczanych przez Kościół Katolicki na działalność charytatywną w całości środków uzyskiwanych przezeń $\mathrm{z}$ otto per mille była poruszana również w ramach komisji parytetowej, ponieważ już od połowy lat 90. XX wieku przedstawiciele rządu apelowali o przywrócenie w tym zakresie większej równowagi. Natomiast odnosząc się do wydatkowania przez tenże Kościół sporych sum na potrzeby kultu, przedstawiciele rządu w komisji parytetowej zwracali uwagę na niewłaściwość praktyki polegającej na konieczności wykupienia biletu w celu wejścia do niektórych świątyń poza godzinami nabożeństw ${ }^{32}$.

Krytykę Trybunału Obrachunkowego wywołała ponadto wysokość kwot wydawanych przez Kościół Katolicki i niektóre inne związki wyznaniowe na kampanie, których celem jest przekonanie podatników do przekazywania im środków pochodzących z $0,8 \%$ podatku dochodowego od osób fizycznych. Na podstawie informacji dotyczących kontraktów zawartych z RAI (Radiotelevisione italiana - włoski publiczny nadawca

\footnotetext{
30 Zob. Raport z 2014 r., s. 7-8.

31 Tamże, s. 31.

32 Tamże, s. 34-36.
} 
radiowo-telewizyjny) wskazano, że w latach 1998-2013 Kościół Katolicki corocznie wydawał na promocję prowadzoną $\mathrm{w}$ publicznym radio i telewizji od 3,1 do 4,65 mln euro, co nakazuje postawić pytanie dotyczące zachowania właściwych proporcji ${ }^{33}$.

W raporcie z 2014 r. krytyce poddano także niedostateczną transparentność systemu finansowania związków wyznaniowych z wykorzystaniem rozwiązań prawnopodatkowych, bez której trudno mówić o właściwej kontroli wydatkowania środków publicznych. Zauważono, że sprawozdania komisji parytetowej oceniającej funkcjonowanie systemu finansowania ustanowionego w ustawie $\mathrm{nr} 222$ z 1985 r. nigdy nie były odpowiednio popularyzowane. Za niedostateczne uznano również informowanie opinii publicznej o wielkości środków uzyskiwanych przez związki wyznaniowe (a zwłaszcza Kościół Katolicki) z 0,8\% podatku dochodowego od osób fizycznych $^{34}$. Odnosząc się do kwestii związanych z transparentnością omawianego systemu, w kolejnych raportach odnotowano już pewną poprawę. W konsekwencji krytyki sformułowanej przez Trybunał Obrachunkowy informacje dotyczące rozdysponowania środków pochodzących z otto per mille nie tylko pojawiły się bowiem na stronie Ministerstwa Ekonomii i Finansów ${ }^{35}$, ale i zostały szerzej uwzględnione na stronie Prezydium Rady Ministrów ${ }^{36}$.

Kolejnym przedmiotem krytyki Trybunału Obrachunkowego stała się powierzchowność i ogólność sprawozdań sporządzanych przez związki wyznaniowe z wykorzystania otrzymywanych środków. Podniesiono przy tym, że sprawozdania te, chociaż są składane Ministrowi Spraw Wewnętrznych (który przekazuje je ponadto Ministrowi Ekonomii i Finansów), nie tylko nie podlegają właściwie żadnej weryfikacji, ale nie wzbudzają też de facto żadnego zainteresowania władz publicznych, ponieważ jedyną instytucją de iure wyraźnie uprawnioną do zajmowania się powstającymi na

33 Tamże, s. 30.

34 Tamże, s. 27-28.

35 Zob. http://www1.finanze.gov.it/finanze2/pagina_dichiarazioni/ottoxmille.php \#navigazione_dinamica [dostęp: 29.12.2018].

36 Otto per mille dell'Irpef a diretta gestione della Chiesa cattolica e delle altre confessioni religiose, http://presidenza.governo.it/USRI/confessioni/ottoxmille.html; Otto per mille dell'Irpef a diretta gestione statale, http://presidenza.governo.it/DICA/OTTO_X_ MILLE_2014/approfondimenti/procedimento_2015.html [dostęp: 29.12.2018]. 
tym gruncie wątpliwościami jest odpowiednia komisja parytetowa (i np. w ramach komisji utworzonej zgodnie z ustawą nr 222 z 1985 r. przedstawiciele rządu od dłuższego czasu kwestionują zasadność finansowania ze środków uzyskiwanych z asygnaty podatkowej działalności trybunałów kościelnych oraz kościelnych środków masowego przekazywania). Zdaniem Trybunału obowiązujący stan prawny nie oznacza jednak zwolnienia resortu spraw wewnętrznych z obowiązku kontrolowania zgodności wydatków ponoszonych przez związki wyznaniowe z przepisami ustawowymi, natomiast informacje o ewentualnych nieprawidłowościach powinny być przekazywane Prezydium Rady Ministrów oraz Ministerstwu Ekonomii i Finansów, do których należy rozważenie możliwość podjęcia stosownych inicjatyw administracyjnych bądź legislacyjnych ${ }^{37}$.

\section{PAŃSTWO JAKO DYSPONENT ŚRODKÓW POCHODZĄCYCH Z OTTO PER MILLE}

Bardzo surowa krytyka została skierowana przez Trybunał Obrachunkowy pod adresem władz państwowych w związku z całkowitym niemal lekceważeniem roli państwa jako dysponenta środków uzyskiwanych z asygnaty podatkowej. W raporcie z 2014 r. zwrócono przede wszystkim uwagę, że w ciągu ćwierćwiecza funkcjonowania omawianego rozwiązania, państwo - jako jedyny podmiot konkurujący o fundusze pochodzące z tego źródła - zupełnie nie angażowało się w akcje, których celem miałoby być przekonanie podatników do dokonania wyboru na jego rzecz. W konsekwencji doszło do społecznej marginalizacji inicjatyw publicznych realizowanych dzięki środkom uzyskiwanym z otto per mille oraz do znaczącego zmniejszenia się liczby podatników wskazujących państwo jako dysponenta tychże środków ${ }^{38}$.

W raporcie z 2014 r. ze zdziwieniem przyjęto fakt, że do podjęcia działań promujących państwo jako podmiot uprawniony do otrzymywania funduszy z asygnaty podatkowej nie skłoniło właściwych władz nawet rozszerzenie katalogu celów, na jakie mogą być przez nie wydatkowane uzyskiwane

37 Raport z 2014 r., s. 44-45; Raport z 2016 r., s. 29-30.

38 Raport z 2014 r., s. 47-48. 
z tego źródła środki. Na podstawie art. 1 ust. 206 ustawy z 27 grudnia 2013 r. (nr 147) ${ }^{39}$ do zwalczania głodu w świecie, usuwania konsekwencji klęsk żywiołowych, opieki nad uchodźcami oraz konserwacji dóbr kultury rzeczywiście dodano bowiem cel, na który - zgodnie ze stanowiskiem Trybunału - włoskie społeczeństwo jest szczególnie uwrażliwione, a więc modernizację, zabezpieczanie i dostosowanie antysejsmiczne nieruchomości będących własnością publiczną i przeznaczonych na nauczanie szkolne $e^{40}$.

Stosowane przez rząd wyjaśnienie braku akcji promujących państwo jako destynatariusza środków pochodzących z otto per mille wiąże się z jeszcze poważniejszym zarzutem sformułowanym przez Trybunał Obrachunkowy. Okazało się bowiem, że rezygnacja z omawianych akcji promocyjnych dyktowana była świadomością faktycznego wydatkowania tych środków w sposób niezgodny z ustawą nr 222 z 1985 r. W rzeczywistości trafiające do państwa wpływy $\mathrm{z}$ asygnaty podatkowej były często wykorzystywane na zrównoważenie budżetu lub na realizację celów spoza katalogu ujętego w tym akcie normatywnym. Ujawniono, że tego rodzaju sytuacje zdarzały się właściwie od początku stosowania instytucji otto per mille, a od 2004 r. są one wręcz regułą. W latach 1995-2014 przyjęto ponad 40 aktów normatywnych, w których przewidziano skorzystanie ze środków pochodzących z tego źródła w sposób sprzeczny z przepisami ustawy $\mathrm{nr} 222$ z $1985 \mathrm{r}^{41}$ Środki pochodzące z asygnaty podatkowej wykorzystywano nawet na interwencje militarne poza granicami Włoch (w Albanii i na Bałkanach). Wydatkowano je również np. na potrzeby obrony cywilnej, na częstotliwości radiowo-telewizyjne oraz na wznoszenie budynków więziennych. W latach 2011-2012 na cele wymienione w katalogu zawartym w ustawie nr 222 z 1985 r. państwo nie przeznaczyło zupełnie żadnych środków pochodzących z asygnaty podatkowej, natomiast w 2013 r. w sposób zgodny z tym aktem normatywnym wydatkowano jedynie 0,24\% państwowych wpływów z tego źródła. W latach 1991-2014, w konsekwencji nadzwyczajnych decyzji, w sposób

39 Ustawa z dnia 27 grudnia 2013 r., nr 147. Disposizioni per la formazione del bilancio annuale e pluriennale dello Stato (Legge di stabilità 2014), G. U. nr 302 z 27 grudnia 2013 r. - Supplemento Ordinario.

40 Zob. Raport z 2014 r., s. 4 i 46.

41 Zob. wykaz zamieszczony w załączniku nr 10 do raportu z 2014 r. (s. 95-97). 
sprzeczny z ustawą nr 222 z 1985 r. wydatkowano aż 68,6\% środków uzyskanych przez państwo z otto per mille. Co więcej, na podstawie przepisów dotyczących budżetu państwa bardzo poważne redukcje środków pochodzących z tego źródła przewidziano również na kolejne lata (niejednokrotnie bez jakiegokolwiek ograniczenia czasowego). W kontekście stwierdzonych nieprawidłowości Trybunał skrytykował również fakt, że nawet w latach, w których całość państwowych środków z asygnaty podatkowej przeznaczono na cele spoza katalogu zawartego w ustawie nr 222 z 1985 r., dokonywano skrupulatnej oceny i selekcji wniosków o finansowanie inicjatyw odpowiadających tym celom. Jak stwierdzono, efektem takiej praktyki jest jedynie marnowanie energii urzędników i środków publicznych, z których są oni opłacani ${ }^{42}$.

Zgodnie z opinią Trybunału Obrachunkowego, wyrażoną w raporcie z 2014 r., na krytykę zasługuje także praktyka rozpraszania środków uzyskiwanych przez państwo z $0,8 \%$ podatku dochodowego od osób fizycznych, które są wydawane przez państwo na różnorodne, niepowiązane ze sobą cele szczegółowe. Za właściwsze uznano koncentrowanie posiadanych funduszy na realizacji mniejszej liczby projektów mających szczególne znaczenie. Bardziej odpowiadałoby to bowiem zakładanej nadzwyczajności realizowanych w tym trybie interwencji, a nadto wymuszałoby podjęcie jakichś świadomych decyzji kierunkowych, których w obecnej rzeczywistości wyraźnie brakuje. Dostrzeżono ponadto, że wbrew obowiązującym przepisom wykonawczym ${ }^{43}$, środki ostatecznie wydatkowane zgodnie z ustawą nr 222 z 1985 r. nie są rozdzielane równomiernie pomiędzy przewidziane $\mathrm{w}$ niej cele. Jak wynika $\mathrm{z}$ przeprowadzonych analiz, w latach 1998-2006 większość funduszy uzyskiwanych przez państwo w konsekwencji decyzji podatników dotyczących $0,8 \%$ podatku dochodowego od osób fizycznych była wykorzystywana na konserwację dóbr kultury (68\%), natomiast na inicjatywy mające na celu zwalczanie głodu w świecie wydatkowano jedynie 4\% środków (wskaźniki dotyczące

42 Raport z 2014 r., s. 51-55.

43 Zob. rozporządzenie (decreto) Prezydenta Republiki z dnia 10 marca 1998 r., nr 76. Regolamento recante criteri e procedure per l'utilizzazione della quota dell'otto per mille dell'IRPEF devoluta alla diretta gestione statale, G. U. nr 81 z 7 kwietnia 1998 r. 
dwóch pozostałych celów wynosiły: usuwanie skutków klęsk żywiołowych $-19 \%$, pomoc uchodźcom - 9\%) ${ }^{44}$.

Analizując wykorzystywanie funduszy uzyskiwanych przez państwo $\mathrm{z}$ asygnaty podatkowej, za niewłaściwą uznano również praktykę wydatkowania ich na konserwację dóbr kultury będących własnością związków wyznaniowych oraz na realizację innych projektów zgłaszanych przez podmioty wyznaniowe (dotyczących np. zwalczania głodu w świecie). Zauważono, że przy tworzeniu obecnego systemu finansowania związków wyznaniowych wyraźnie kierowano się dążeniem do zapewnienia podatnikom możliwości wyboru celów niekościelnych, w związku z czym w opinii Trybunału Obrachunkowego - przyjęta praktyka musi być uznana za aberrację. Rozwiązanie mające być alternatywą dla inicjatyw o charakterze konfesyjnym jest bowiem wykorzystywane na ich dodatkowe finansowanie. Wyrażono przy tym pogląd, że tego rodzaju wydatki, w razie uznania ich zasadności, powinny obciążać inne części budżetu państwa ${ }^{45}$.

$\mathrm{W}$ omawianych raportach krytycznie odniesiono się również do braku należytej kontroli nad wydatkowaniem państwowych środków pochodzących z otto per mille. Zwrócono uwagę, że w ostatnim pięcioleciu cofnięto tylko jedną dotację przyznaną z tego źródła ${ }^{46}$. Za niewłaściwą uznano też praktykę - zmienioną dopiero w 2013 r. - wypłacania całej kwoty dotacji w jednej transzy, bez uzależniania wypłat kolejnych rat od właściwej realizacji wcześniejszych etapów. Krytycznie odniesiono się ponadto do zasad, zgodnie z którymi procedura wyboru projektów zasługujących na finansowanie ze środków państwowych pochodzących z asygnaty podatkowej nie obejmuje żadnych kontroli realizowanych na miejscu prowadzenia działalności przez wnioskujący podmiot, ani też nie obejmuje wymogu legitymowania się odpowiednimi gwarancjami bankowymi lub ubezpieczeniowymi ${ }^{47}$.

44 Raport z 2014 r., s. 57-59.

45 Szczególnie mocno skrytykowano decyzję o sfinansowaniu w omawianym trybie prac nad odnowieniem niektórych elementów zabudowań Papieskiego Uniwersytetu Gregoriańskiego. Pomimo tego, że chodzi o nieruchomości posiadające przymiot eksterytorialności, które ponadto - jak stwierdzono - nie odznaczają się szczególnymi walorami artystycznymi czy historycznymi, przeznaczono na ten cel znaczące środki (1.441.965 euro w 2002 r., 370.000 euro w 2004 r., 442.500 euro w 2007 r. oraz 457.445 euro w 2009 r.). Raport z 2014 r., s. 60-62.

46 Raport z 2014 r., s. 64-65.

47 Tamże, s. 71-72. 


\section{BRAK RÓWNOŚCI POMIĘDZY ZWIĄZKAMI WYZNANIOWYMI}

Krytykę sformułowaną przez Trybunał Obrachunkowy wywołał również brak równości pomiędzy związkami wyznaniowymi, wyraźnie widoczny na gruncie przepisów odnoszących się do asygnaty podatkowej. Tylko niektóre z tych podmiotów (mianowicie te, których stosunki z państwem zostały uregulowane przez ustawy oparte na uprzednich porozumieniach) mają bowiem prawo do udziału w podziale środków z otto per mille. Oceniając to rozwiązanie, wyrażono opinię, że jego obowiązywanie wiąże się z ryzykiem potwierdzania istniejącego stanu ,niedoskonałego pluralizmu wyznaniowego" (pluralismo confessionale imperfetto) ${ }^{48}$. Zwrócono przy tym uwagę, że uzyskanie dostępu do środków z asygnaty podatkowej stanowi często główny cel starań o zawarcie porozumienia z państwem i uzyskanie opartej na nim regulacji ustawowej. W konsekwencji tego porozumienia - o których mowa - z instrumentu ochrony tożsamości poszczególnych grup religijnych stały się przede wszystkim instrumentem pozwalającym uzyskać dostęp do środków pochodzących z otto per mille. Tymczasem - jak zauważono - dostrzegalna standaryzacja odnoszących się do tego postanowień układowych pozwalałaby na sformułowanie na ich podstawie przepisów prawa powszechnego, odnoszących się do wszystkich związków wyznaniowych ${ }^{49}$.

Formułując omawianą krytykę, zauważono, że włoskie społeczeństwo, również pod względem wyznaniowym, staje się coraz bardziej pluralistyczne. Rozciągnięcie na wszystkie związki wyznaniowe prawa korzystania ze środków pochodzących z asygnaty podatkowej byłoby nie tylko właściwą odpowiedzią na ten proces, ale i doprowadziłoby do zmniejszenia wielkości funduszy przypadających podmiotom najbardziej korzystającym z tego rozwiązania, a więc Kościołowi Katolickiemu oraz państwu. Wskazano przy tym, że postulowana zmiana mogłaby zostać przeprowadzona z wykorzystaniem ustawy niemającej podstawy układowej. Opracowując jej treść - zdaniem Trybunału Obrachunkowego - należałoby rozważyć również uwzględnienie ,podmiotów kierujących się negatywnym celem religijnym" (enti che perseguono un fine di religione 'negativo'). Odwo-

\footnotetext{
48 Raport z 2015 r., s. 24.

49 Raport z 2014 r., s. 18.
} 
łano się przy tym do rozwiązań obowiązujących w Niemczech, Belgii i Norwegii. Zwrócono też uwagę, że środki pochodzące z otto per mille są przeznaczane przez związki wyznaniowe nie tylko na cele stricte religijne, ale i na cele humanitarne, społeczne czy opiekuńcze, a te z powodzeniem mogłyby być realizowane również przez podmioty niemające charakteru religijnego ${ }^{50}$.

Braku równości między związkami wyznaniowymi dotyczy również uwaga odnosząca się do sposobu wypłacania środków z otto per mille. Reguła znajdująca zastosowanie do Kościoła Katolickiego (zgodnie z którą Konferencja Episkopatu Włoch otrzymuje każdego roku w czerwcu tytułem zaliczki środki obliczone na podstawie danych sprzed trzech lat; natomiast wyrównanie, obliczone już na podstawie deklaracji podatników dotyczących danego roku podatkowego, dokonywane jest w styczniu trzeciego kolejnego okresu podatkowego) nie ma bowiem zastosowania do pozostałych związków wyznaniowych (w ich przypadku całość należnych im środków wypłacana jest z trzyletnim przesunięciem) $)^{51}$.

\section{BRAK KONTROLI NAD PRAWIDŁOWOŚCIĄ}

FUNKCJONOWANIA SYSTEMU PRZEKAZYWANIA INFORMACJI

O WYBORACH DOKONYWANYCH PRZEZ PODATNIKÓW

Uwagę kontrolujących zwrócił również brak należytych gwarancji, że decyzje podatników dotyczące wyboru destynatariusza środków pochodzących z otto per mille nie zostaną zniekształcane na dalszych etapach procesu przetwarzania informacji. Już w raporcie z 2014 r. skrytykowano fakt, że nie dokonuje się niemal żadnych analiz prawidłowości funkcjonowania wykorzystywanych w tym celu systemów elektronicznych ani też nie kontroluje się rzetelności uczestniczących w tym procesie centrów poradnictwa podatkowego ( $\mathrm{Caf}$ ). Zwrócono przy tym uwagę, że niektóre

50 Tamże, s. 19.

51 Tamże, s. 37. 
z takich centrów są wyraźnie powiązane ze związkami wyznaniowymi, co rodzi sytuację możliwego konfliktu interesów ${ }^{52}$.

Kontrole przeprowadzone przez Agencję Dochodów w konsekwencji krytycznych opinii Trybunału ${ }^{53}$ potwierdziły zasadność niektórych ze sformułowanych przezeń zarzutów. Stwierdzono bowiem zarówno przypadki nierzetelnego przekazywania przez centra poradnictwa podatkowego do Agencji Dochodów informacji o decyzjach podjętych przez podatników w sprawie wskazania destynatariusza $0,8 \%$ podatku dochodowego od osób fizycznych (dotyczyło to 1,67\% deklaracji skontrolowanych w 2014 r. oraz nieokreślonych procentowo, nielicznych deklaracji skontrolowanych w 2015 r.), jak i przypadki nieprzechowywania przez te centra, wbrew obowiązującym przepisom, dokumentacji pozwalającej na zweryfikowanie rzetelności ich działania (5\% deklaracji poddanych kontroli w 2014 r. oraz nieokreślona procentowo liczba deklaracji skontrolowanych w 2015 r.). W odniesieniu do tej pierwszej kwestii stwierdzono przy tym wyraźnie, że stosowane procedury oraz wykorzystywane formularze i programy nie dają pewności, że decyzja podjęta przez podatnika nie zostanie zniekształcona przed jej przekazaniem do Agencji Dochodów. Stwierdzono ponadto istnienie zagrożenia niedopuszczalnego wpływania przez pracowników centrów na decyzje podejmowane przez podatników. Odnosząc się do działalności chrześcijańskich organizacji związkowych, zauważono w tym kontekście, że dyrektor generalny centrów należących do Chrześcijańskiego Ruchu Pracowników (Movimento Cristiano Lavolatori) wskazywał podwładnym, że powinni sugerować podatnikom dokonanie wyboru na rzecz Kościoła Katolickiego, natomiast na stronie internetowej centrów

52 Tamże, s. 41-43.

53 Jeszcze w 2014 r. przeprowadzono kontrolę działalności centrów prowadzonych przez Chrześcijańskie Stowarzyszenia Włoskich Pracowników (Associazioni Cristiane Lavoratori Italiani) oraz Chrześcijański Ruch Pracowników (Movimento Cristiano Lavoratori). Natomiast w 2015 r. - biorąc pod uwagę nie tylko asygnatę na rzecz związków wyznaniowych (otto per mille), ale i asygnatę na rzecz organizacji pożytku publicznego (cinque per mille) - kontrolą objęto centra prowadzone przez zawodowe organizacje związkowe (Confederazione Italiana Sindacati Lavolatori, Confederazione Italiana Sindacati Autonomi Lavolatori, Unione Nazionale Sindacale Imprenditori e Coltivatori, Federazione Nazionale Autonoma Piccoli Imprenditori, Confederazione Nazionale Coltivatori Diretti), a także Caf Centrimpresa i Caf Italia. Zob. raport z 2018 r., s. 19-21. 
prowadzonych przez Chrześcijańskie Stowarzyszenie Włoskich Pracowników (Associazioni Cristiane Lavoratori Italiani) w 2014 r. zamieszczony był link do strony konkursu I feel $\mathrm{Cud}$, promującego dokonywanie wyborów na rzecz tego Kościoła. Stwierdzono ponadto, że odsetek wyborów dokonywanych na rzecz Kościoła Katolickiego przez podatników korzystających z tych centrów był wyższy od średniej krajowej $(68,42 \%$ w przypadku centrów prowadzonych przez Chrześcijański Ruch Pracowników oraz $82,34 \%$ w przypadku centrów należących do Chrześcijańskiego Stowarzyszenia Włoskich Pracowników).

\section{STANOWISKO KOŚCIOŁA KATOLICKIEGO I INNYCH ZWIĄZKÓW WYZNANIOWYCH}

Zgodnie z procedurą stosowaną przez Trybunał Obrachunkowy prawo do przedstawienia własnego stanowiska wobec treści raportu z 2014 r. posiadały również kościoły i inne związki wyznaniowe, które uczestniczą w systemie finansowania opartym na asygnacie podatkowej. Stanowiska zajęte przez nie wobec krytyki sformułowanej w raporcie z 2014 r. zostały zreferowane w raporcie sporządzonym w $2015 \mathrm{r}$.

Opinia Konferencji Episkopatu Włoch została wyrażona w skierowanym do Trybunału piśmie $\mathrm{z}$ dnia 21 września $2015 \mathrm{r} .{ }^{54} \mathrm{~W}$ wystąpieniu tym uznano potrzebę doskonalenia obowiązujących rozwiązań i dostrzeżono zasadność uwag odnoszących się do braku wymaganej transparentności działań władz publicznych. Za problematyczną uznano natomiast krytykę tzw. „wyborów niewyrażonych”, nie zgadzając się ponadto z uzasadnianiem postulatów reformy wielkością kwot uzyskiwanych z asygnaty podatkowej przez Kościół Katolicki. Zwrócono uwagę na fakt, że istotę rozwiązania określanego jako otto per mille od początku stanowiło oddanie obywatelom prawa do decydowania o podziale wpływów z $0,8 \%$ podatku dochodowego od osób fizycznych, z odwołaniem się do mechanizmów de-

54 Pełna treść tego pisma została opublikowana na stronie internetowej Obserwatorium Prawno-Legislacyjnego (Osservatorio Giuridico-Legislativo) Konferencji Episkopatu Włoch: https://ogl.chiesacattolica.it/2016/07/25/8-per-mille-intervento-della-cei-del-21-settembre-2015/ [dostęp: 22.12.2018]. 
mokracji bezpośredniej. Zauważono, że również przy dokonywaniu wyboru przedstawicieli do różnego rodzaju ciał kolegialnych, odsetek obywateli biorących udział w wyborach nie decyduje o liczbie rozdzielanych mandatów. Podkreślono, że racje stojące za przyjęciem tego rozwiązania nie utraciły swej aktualności. Konferencja Episkopatu Włoch zwróciła przy tym uwagę na bezpodstawność twierdzenia, że powstrzymanie się przez podatnika od skorzystania z prawa wyraźnego wyboru destynatariusza $0,8 \%$ podatku dochodowego od osób fizycznych stanowi znak braku akceptacji dla całego systemu. Zauważono też, że zgodnie z obowiązującymi przepisami prawo i obowiązek dokonywania okresowych ocen funkcjonowania systemu oraz formułowania propozycji zmian powierzono komisji parytetowej funkcjonującej na podstawie art. 49 ustawy nr 222 z 1985 r. Tymczasem wszystkie dotychczasowe oceny formułowane przez to gremium - pomimo różnego rodzaju uwag szczegółowych - pozytywnie odnoszą się do funkcjonowania systemu finansowania Kościoła Katolickiego we Włoszech ${ }^{55}$.

Podobne do opinii wyrażonej przez Konferencję Episkopatu Włoch było w swej wymowie stanowisko przedstawicieli Włoskiej Unii Hinduistycznej. W nocie z 22 września 2015 r. zwrócili oni uwagę, iż powstrzymanie się od dokonania wyraźnego wyboru destynatariusza powinno być również traktowane jako świadomy wybór, mający swoje konsekwencje dla podziału środków pochodzących z otto per mille. Podkreślono przy tym, że nawet jeśli za tego typu postawą stałaby ignorancja co do treści obowiązującego prawa, to i tak nie ma podstaw do twierdzenia, że jest to okoliczność je kompromitująca. Zgodnie z powszechnie akceptowanymi zasadami tego rodzaju ignorancję należałoby uznać za efekt niedbalstwa ze strony podatnika, ponieważ omawiane rozwiązanie $\mathrm{w}$ niezmienionym kształcie obowiązuje już od wielu lat ${ }^{56}$.

W odmiennym tonie wypowiedzieli się natomiast przedstawiciele Włoskiej Unii Kościołów Adwentystów Dnia Siódmego. W piśmie z 15 czerwca 2015 r. za punkt wyjścia przyjęli oni spostrzeżenie, że wysokość kwot trafiających dzięki asygnacie podatkowej do Kościoła Katolickiego nie znajduje żadnego odpowiednika w przypadku pozostałych związków wy-

55 Raport z 2015 r., s. 17-18.

56 Tamże, s. 18. 
znaniowych, objętych omawianym systemem finansowania, a przepisy prawa powszechnego nie są zbyt korzystne dla mniejszości religijnych. Pomimo tego wyrażono gotowość przystąpienia do prac zmierzających do modyfikacji obowiązujących unormowań. Za słuszną uznano bowiem ideę, zgodnie z którą konsekwencją powstrzymania się przez podatników od dokonania wyraźnego wyboru destynatariusza środków z otto per mille powinno być pozostawienie ich w dyspozycji państwa (choć z możliwym wyraźnym wskazaniem celów, na jakie mogą być one wydatkowane) ${ }^{57}$.

Jeszcze inne stanowisko zajęli przedstawicieli Chrześcijańskiej Unii Ewangelicko-Baptystycznej Włoch. Wyrazili oni przekonanie, że rzeczywisty problem nie polega na tym, czy przy podziale środków z asygnaty podatkowej uwzględniane będą jedynie wyraźne wybory podatników, czy też również tzw. „wybory niewyrażone”. Jak zauważono, w systemie demokratycznym jest czymś naturalnym, że ci, którzy decydują się na uchylenie się od podejmowania własnych decyzji i wyrażania ich, zdają się na decyzje podejmowane przez innych. W nocie z 22 maja 2015 r. za istotę problemu uznano natomiast brak jakiejkolwiek korelacji dochodów osiąganych przez Kościół Katolicki z asygnaty podatkowej z funduszami trafiającymi do tego związku wyznaniowego w konsekwencji brzmienia przepisów odnoszących się do innych kwestii. Jak podkreślono, inaczej jest w przypadku mniejszościowych związków wyznaniowych, ponieważ one - poza asygnatą podatkową - nie mogą liczyć na żadne inne dotacje z funduszy publicznych. W konsekwencji ewentualne ograniczenie wpływów możliwych do uzyskania dzięki instytucji otto per mille obróciłoby się przede wszystkim przeciwko nim. Zasugerowano więc rozważenie, czy właściwym rozwiązaniem problemów dostrzeżonych przez Trybunał Obrachunkowy nie powinno być ustanowienie limitu funduszy trafiających z asygnaty podatkowej do Kościoła Katolickiego. Wyrażono przy tym przekonanie, że państwo nie powinno partycypować w podziale kwot z tego źródła. Za właściwsze uznano ewentualne uwzględnienie możliwości przyznania podatnikom prawa wyłączenia przypadającej na nich części środków z otto per mille z podziału odwołującego się do tzw. „wyborów niewyrażonych" 58 .

57 Tamże, s. 18-19.

58 Tamże, s. 19. 


\section{KONSEKWENCJE RAPORTÓW TRYBUNAŁU OBRACHUNKOWEGO}

Publikacja omawianych raportów - zgodnie z ich naturą - nie spowodowała żadnych bezpośrednich konsekwencji. Sformułowana w nich krytyka oraz postulaty zmian będą mogły wywrzeć rzeczywisty wpływ na stosowane rozwiązania jedynie pod warunkiem przyjęcia ich za własne przez władze publiczne odpowiedzialne za kształt obowiązującego prawa ${ }^{59}$. Natomiast autorzy komentujący opinie wyrażone przez Trybunał postrzegają je zazwyczaj w kategoriach stanowczego wezwania do podjęcia reformy systemu finansowania związków wyznaniowych (a przede wszystkim Kościoła Katolickiego, któremu - jak to ujmują, podążając śladem wytyczonym w raportach - „mechanizm oto per mille pozwolił na zarządzanie wciąż narastającym strumieniem środków publicznych o prawdopodobnie nieoczekiwanej wielkości" $\left.{ }^{60}\right)$. Koncentrują się oni zwłaszcza na krytyce tzw. „wyborów niewyrażonych” (widząc w nich mechanizm zmuszający do udziału w finansowaniu związku wyznaniowego, do którego się nie należy) oraz nieuzasadnionym uprzywilejowaniu Kościoła Katolickiego i innych związków wyznaniowych objętych omawianym systemem finansowania (przy utrzymywaniu prawnego upośledzenia pozostałych grup religijnych, w przypadku których dostęp do środków z asygnaty podatkowej jest zablokowany przez faktyczny brak możliwości zawarcia porozumienia, o którym mowa w art. 8 ust. 3 Konstytucji Republiki Włoskiej). Autorzy ci z ubolewaniem zauważają, że publikacja omawianych raportów nie spotkała się z żadną bezpośrednią reakcją właściwych władz publicznych $^{61}$.

Za efekt krytyki sformułowanej przez Trybunał Obrachunkowy należy natomiast uznać postulat podjęcia dyskusji na temat zmiany wysokości asygnaty podatkowej, z jakim w 2016 r. wystąpili przedstawiciele rządu w komisji parytetowej powołanej do oceny funkcjonowania systemu finansowania Kościoła Katolickiego. Na ostatnich etapach prac nad podsu-

59 Zwraca na to uwagę m.in. Elefante 2015, 252.

${ }^{60}$, ,... il) meccanismo dell'otto per mille il quale (...) ha consentito alla Chiesa cattolica la gestione di un flusso crescente di denaro pubbico di entità, probabilimente, inaspettata". Parisi 2015, 171. Por. np. raport z 2018 r., s. 25.

61 Zob. Parisi 2015; Casuscelli 2015, 3-4. 
mowaniem okresu 2011-2013 sformułowali oni wniosek, aby przy dokonywaniu kolejnej trzyletniej oceny (odnoszącej się do lat 2014-2016) pod dyskusję poddać również kwestię zmniejszenia wielkości części podatku dochodowego od osób fizycznych, którą podatnicy mogą skierować do związków wyznaniowych. Jak stwierdzono, wchodzące w grę kwoty oraz przedłużający się kryzys ekonomiczny powodują, że podjęcie refleksji na ten temat powinno być uznane za konieczność. Przedstawiciele strony kościelnej odpowiedzieli jednak, że nie dostrzegają racji przemawiających za podjęciem propozycji strony rządowej. Wniosek ten wsparto odwołaniem do pozytywnych rezultatów, jakie dzięki temu systemowi udało się osiągnąć z korzyścią nie tylko dla samego Kościoła, ale i dla całego społeczeństwa, a zwłaszcza najbardziej potrzebujących grup społecznych. Zwrócono też uwagę, że przeciwko zmianom przemawia pozytywna ocena wyrażana przez podatników wobec omawianej działalności Kościoła, czego znakiem jest stałe wskazywanie Kościoła Katolickiego jako destynatariusza środków pochodzących z otto per mille przez znaczącą grupę podatników ${ }^{62}$.

Związek z raportami dotyczącymi instytucji otto per mille posiada również poselski projekt ustawy konstytucyjnej (firmowany przez pięciu deputowanych z ruchu Liberi e Uguali - Wolni i Równi, w tym czterech członków Włoskiej Lewicy - Sinistra Italiana), złożony 10 marca 2016 r. ${ }^{63}$ Jego istotą są przepisy, zgodnie z którymi miałoby dojść do likwidacji przyznawania związkom wyznaniowym kwot pochodzących z otto per mille w ramach tzw. „wyborów niewyrażonych”, oraz przyjęcie, że środki, które nie są objęte wyraźnymi decyzjami podatników, mają trafiać do państwa i być wykorzystywane na cele związane ze zwalczaniem ubóstwa. O specyfice tego projektu decyduje m.in. znajdująca się w uzasadnieniu sugestia, że chociaż zamiarem jego autorów było uchwalenie ustawy bez zawierania z Kościołem jakichkolwiek umów (stąd jej konstytucyjny charakter), to jednak możliwe wydaje się uzyskanie dla niej pozytywnej opinii

62 Relazione della Commissione paritetica nominata dal Governo italiano e della Conferenza episcopale italiana ai sensi dell'articolo 49 della legge 20 maggio 1985, n. 222, załącznik nr 2 do raportu Trybunału Obrachunkowego z 2018 r.

${ }^{63}$ Proposta di legge constituzionale. Disposizioni concernenti la disciplina del finanziamento di attività religiose e caritative della Chiesa cattolica e di altre confessioni religiose e del sostentamento del clero (3667); http://www.camera.it/leg17/126?tab=2\&leg=17\&id Documento $=3667 \&$ sede $=\&$ tipo $=[$ dostęp: 20.12 .2018$]$. 
papieża Franciszka. Nad omówionym projektem nie podjęto jednak żadnych faktycznych prac.

Skutek raportów Trybunału Obrachunkowego stanowi ponadto wezwanie rządu do podjęcia rokowań ze Stolicą Apostolską, w celu zmiany przepisów określających przeznaczenie kwot pochodzących z tzw. „wyborów niewyrażonych". Z wnioskiem w tej kwestii (wniosek 1-01313 z 24 czerwca 2016 r.) wystąpiła grupa 26 deputowanych należących do ugrupowań opozycyjnych, które wchodzą w skład lewicowego ruchu Liberi e Uguali (do których przyłączył się jeden poseł niezrzeszony) ${ }^{64}$.

Przynajmniej pośrednio z krytyką sformułowaną przez Trybunał Obrachunkowy powiązana jest również decyzja podjęta przez Konferencję Episkopatu Włoch podczas 69 Zgromadzenia Plenarnego w dniach 16-19 maja 2016 r. Zmieniono wówczas przepisy wykonawcze dotyczące podziału środków z otto per mille na poziomie diecezji oraz odnoszące się do związanej z tym sprawozdawczości. Jak wynika z treści uchwały, została ona podporządkowana dążeniu do potwierdzenia i wzmocnienia starań o zapewnienie skrupulatności rozliczeń i należytej transparentności podejmowanych działań ${ }^{65}$.

\section{UWAGI KOŃCOWE}

Omówione raporty włoskiego Trybunału Obrachunkowego powinny być niewątpliwie uznane za ważny głos w dyskusji dotyczącej instytucji otto per mille oraz odnoszących się do niej rozwiązań praktycznych. Oparcie opinii dotyczącej włoskiej asygnaty podatkowej wyłącznie na krytyce sformułowanej w tych dokumentach byłoby jednak błędem.

Za przekonujące należy uznać w szczególności zarzuty dotyczące wykorzystywania przez państwo środków uzyskiwanych z $0,8 \%$ podatku dochodowego od osób fizycznych w sposób niezgodny z przepisami ustawy nr 222 z 1985 r. W konsekwencji takich praktyk rzeczywiście dochodzi do poważnego naruszenia relacji zaufania, jaka powinna istnieć między po-

64 Zob.https://parlamento17.openpolis.it/atto/documento/id/244763 [dostęp:20.12.2018].

${ }_{65}$ Ripartizione e rendiconto a livello diocesano delle somme provenienti dall'otto per mille, "Notiziario della Conferenza Episcopale Italiana" 2016, nr 3, s. 79-80. 
datnikami a władzami publicznymi, zarządzającymi środkami uzyskiwanymi z obowiązujących danin. Na napiętnowanie bez wątpienia zasługują także wszelkie przypadki nierzetelnego przekazywania woli podatników przez podmioty biorące udział $\mathrm{w}$ tym procesie. Uzasadnione jest oczekiwanie, aby środki publiczne (w tym również te, które - zgodnie z wolą podatników - rozdzielane są pomiędzy związki wyznaniowe) wydatkowane były w sposób odznaczający się należytą transparentnością. Zgodzić się też trzeba $\mathrm{z}$ twierdzeniem, że utrzymywanie niejednolitego statusu związków wyznaniowych na gruncie przepisów dotyczących instytucji otto per mille nie odpowiada wymogom sprawiedliwości. Trudno wreszcie się dziwić, że Trybunał Obrachunkowy wyraża troskę o stan włoskich finansów.

W zrelacjonowanych wyżej raportach nie brak jednak również twierdzeń, które nie powinny być przyjmowane bez zastrzeżeń. Do takich należy przede wszystkim krytyka dotycząca tzw. „wyborów niewyrażonych”, przedstawianych w kategoriach przymusowego włączania wszystkich podatników w finansowanie związków wyznaniowych (co musiałoby zostać uznane za naruszenie wolności myśli, sumienia i religii). Jest prawdą, że teza o braku należytego poszanowania woli podatników w unormowaniach odnoszących się do podziału środków z otto per mille obecna jest we włoskiej literaturze przedmiotu właściwie od czasu wprowadzenia tej instytucji prawnej ${ }^{66}$. Z łatwością można też jednak wskazać autorów $\mathrm{z}$ nią polemizujących ${ }^{67}$. Za znamienne trzeba przy tym uznać, że Trybunał Obrachunkowy nie odniósł się do stanowiska organów niewątpliwie właściwszych w tej sprawie, to jest włoskiego Sądu Konstytucyjnego oraz Europejskiego Trybunału Praw Człowieka. Żaden z nich bowiem, pomimo już ponad trzydziestoletniego obowiązywania omawianych rozwiązań, nie wydał żadnego orzeczenia, które by je kwestionowało. Tymczasem przynajmniej dwa ich orzeczenia zasługiwałyby na baczniejszą uwagę. Problematyka odnosząca się do instytucji otto per mille została bowiem podjęta w postanowieniu włoskiego Sądu Konstytucyjnego z 29 grudnia 1995 r. (nr 539) ${ }^{68}$ oraz w wyroku Europejskiego Trybunału Praw Człowieka

66 Obok powoływanej już pracy, której autorem jest Carlo Cardia (Cardia 1992, 278-279), tytułem przykładu można wskazać również opracowanie Vitale 1993, 147.

${ }_{67}$ Zob. np. Feliciani 2006, 460-461; Bachrach 1999, 95-97.

68 Zob. „Giurisprudenza Costituzionale” 1995, z. 6, s. 4465-4467. 
z dnia 29 marca 2007 r. w sprawie Spampinato v. Italy $(23123 / 04)^{69}$. W obu przypadkach skargi zostały uznane za w sposób oczywisty bezzasadne. Faktem co prawda pozostaje, że w obu przypadkach wnioski o rozpatrzenie sprawy nie zostały przygotowane zgodnie z najlepszymi wzorcami staranności, co bez wątpienia przyczyniło się do łatwego oddalenia zarzutów. Jest też jednak prawdą, że w żadnym z tych orzeczeń nie sposób odnaleźć choćby śladu jakiegokolwiek uznania racji przedstawionych przez skarżących, a wyrok strasburski został we włoskiej literaturze przedmiotu uznany nawet (przez autorkę odnoszącą się do niego krytycznie) za legitymizację instytucji otto per mille ${ }^{70}$.

Nie sposób również zgodzić się z twierdzeniem, że nieskorzystanie przez podatnika z prawa wskazania destynatariusza $0,8 \%$ podatku dochodowego od osób fizycznych oznacza bez wątpliwości, iż odnosi się on do omawianej instytucji prawnej krytycznie lub co najmniej z rezerwą. Formułując tę opinię, pominięto w szczególności fakt, że wśród powstrzymujących się od skorzystania z przysługującego im prawa dominują podatnicy, którzy nie są zobowiązani do składania osobnych (rocznych) zeznań podatkowych. Tymczasem wskazanie wybranego destynatariusza środków pochodzących z otto per mille nie wiąże się z żadnymi problemami praktycznymi jedynie w przypadku tych podatników, których taki obowiązek obciąża. Pozostali, w celu skorzystania z prawa czynnego udziału w podziale środków z asygnaty podatkowej, muszą postępować zgodnie ze specjalnie ustanowioną procedurą, która wiąże się już z dodatkowymi kłopotami. W praktyce decyduje się na to tylko ok. 1\% podatników z tej grupy (która liczy obecnie ponad szesnaście milionów), podczas gdy wśród podatników zobowiązanych do składania zeznań odsetek tych, którzy czynnie uczestniczą w omawianej procedurze, przekracza $60 \%{ }^{71}$.

Trudno bez zastrzeżeń przyjąć też opinię, zgodnie z którą - pomimo ponad 30 lat obowiązywania przepisów odnoszących się do instytucji otto per mille - nawet podatnicy „odznaczający się zwykłą starannością, mogą być przekonani, że skutek w postaci przyznania środków następuje jedynie w konsekwencji dokonania wyraźnego wyboru”. Pomijając już fakt braku

${ }_{69}$ Zob. https://hudoc.echr.coe.int/fre [dostęp: 22.12.2018].

70 Zob. Belgiorno de Stefano 2007, 3341-3346.

71 Feliciani 2018, 397. 
jakiegokolwiek oparcia się na odnoszących się do tego badaniach socjologicznych, trzeba zauważyć, że przyjmowanie tego rodzaju założeń powinno skutkować kompromitacją współczesnych systemów prawnych in genere. Pomimo tego, że składające się na nie unormowania są często dużo bardziej skomplikowane od przepisów dotyczących omawianej asygnaty podatkowej i dużo częściej się zmieniają, władze publiczne z reguły wcale się nie angażują w wyjaśnianie ich szerokiemu gronu adresatów norm, przyjmując niewzruszenie, że ostatecznie ignorantia iuris nocet.

Jako wprowadzające w błąd jawi się również stwierdzenie, że uwzględnianie przy podziale środków z otto per mille tzw. „wyborów niewyrażonych" uprzywilejowuje przede wszystkim tych, którzy i tak najbardziej korzystają z systemu finansowania opartego na asygnacie podatkowej, a więc przede wszystkim Kościół Katolicki. Przy uwzględnieniu wartości bezwzględnych trzeba oczywiście stwierdzić, że w konsekwencji obowiązywania tego rozwiązania największe sumy przypadają Kościołowi Katolickiemu. Jednak „współczynnik multiplikacyjny” w przypadku wszystkich beneficjentów uczestniczących w podziale środków uzyskiwanych $\mathrm{z}$ tego źródła jest podobny ${ }^{72}$.

Jest wysoce prawdopodobne, że to właśnie wskazane wyżej motywy zdecydowały o reakcji reprezentantów Kościoła Katolickiego w komisji parytetowej na wniosek przedstawicieli rządu o podjęcie prac nad zmianą przepisów dotyczących instytucji otto per mille, postawiony w kontekście odwołań do raportów sporządzonych przez Trybunał Obrachunkowy. Odpowiadając negatywnie na tę inicjatywę w dniu 19 października 2016 r., podczas posiedzenia zamykającego weryfikację funkcjonowania systemu finansowania Kościoła Katolickiego za lata 2011-2013, jego przedstawiciele zaapelowali o to, aby nie ideologizować omawianego tematu i nie pomijać wkładu Kościoła w dobro wspólne ${ }^{73}$. Z dokumentów odnoszących się do prac komisji zajmujących się systemem finansowania innych związków

72 Zob. raport z 2014 r., s. 16-17, tabela nr 3. Zob. załącznik B do artykułu.

73 „La Parte ecclesiastica esprime l'auspicio che in sede bilaterale possa trovare continuità e rafforzamento un aproccio a questo tema non ideologico, orientato a riconoscere e favorire il servizio reso dalla Chiesa al bene commune". Relazione della Commissione paritetica nominata dal Governo italiano e della Conferenza episcopale italiana ai sensi dell'articolo 49 della legge 20 maggio 1985, n. 222, załącznik nr 2 do raportu Trybunału Obrachunkowego z $2018 \mathrm{r}$. 
wyznaniowych w tym samym okresie wynika zresztą, że przedstawiciele żadnego z nich nie podjęli kwestii potrzeby zmniejszenia środków przypadających tym podmiotom $z$ omawianej asygnaty podatkowej, a niejednokrotnie wyraźnie mówili o znaczeniu tych środków dla funkcjonowania ich wspólnoty ${ }^{74}$. Faktyczne podjęcie dyskusji nad potrzebą zmiany obowiązujących w tym zakresie unormowań będzie w tej sytuacji zależeć od poziomu determinacji rządu jako podmiotu pierwszorzędnie odpowiedzialnego za kształt faktycznych relacji państwa za związkami wyznaniowymi.

\section{BIBLIOGRAFIA}

Astorri, Romeo. 2009. „Le financement des confessions religieuses en Italie”. W: The Financing of Religious Communities in the European Union - Le financement des religions dans les pays de l'Union Européenne, ed. Brigitte Basdevant-Gaudemet, Salvatore Berlingò, 223-233. Leuven - Paris - Dudley, MA: Peeters Publishers.

Bachrach, Riccardo. 1999. "L'Intesa tra la Chiesa Evangelica Luterana In Italia e lo Stato italiano". W: Quaderni della Scuola di Specializzazione in Diritto Ecclesiastico e Canonico, t. 6: Le intese viste dalle confessioni, ed. Mario Tedeschi, 91-98. Napoli: Jovene.

Belgiorno de Stefano, Maria Gabriella. 2007. "La Corte di Strasburgo legittima l'otto per mille alle Chiese italiane". Il Fisco 23/1: 3341-3346.

Cardia, Carlo. 1992. Stato e confessioni religiose. Il regime pattizio. Bologna: Il Mulino.

Cardia, Carlo. 2001. "La legge 222/1985: attuazioni, problemi, prospettive".

W: Dall 'Accordo del 1984 al disegno di legge sulla libertà religiosa. Un quindicennio di politica e legislazione ecclesiastica, ed. Anna Nardini, Giovanni di Nucci, 173-175. Roma: Presidenza del Consiglio dei Ministri, Dipartimento per l'informazione e l'editoria.

74 Zob. sprawozdania zamykające prace komisji parytetowych utworzonych przez Prezydium Rady Ministrów oraz Stół Waldensów, Włoską Unię Chrześcijańskich Kościołów Adwentystów Dnia Siódmego, Zgromadzenia Boże we Włoszech, Związek Gmin Wyznaniowych Żydowskich, Kościół Ewangelicko-Luterański we Włoszech i Chrześcijańską Unię Ewangelicko-Baptystyczną Włoch, w odniesieniu do ich finansowania w okresie 2011-2013; załącznik nr 2 do raportu Trybunału Obrachunkowego z 2018 r. 
Casuscelli, Giuseppe. 2015. "L'otto per mille nella nuova relazione della Corte dei Conti: spunti per una riforma". Stato, Chiese e pluralismo confessionale nr 39 (21 dicembre 2015): 1-45. DOI: 10.13130/1971-8543/6631.

Elefante, Carmela. 2015. "Il sistema dell'otto per mille al vaglio della Corte dei Conti: prime valutazioni e spunti ricostruttivi". Diritto e Religioni 2: 231-252. Elefante, Carmela. 2018. L' "Otto per mille». Tra eguale libertà e dimensione sociale del fattore religioso. Torino: Giappichelli Editore.

Feliciani, Giorgio. 2000. „Finansowanie instytucji kościelnych i utrzymanie duchowieństwa. Doświadczenia włoskie”. W: Systemy finansowania instytucji kościelnych w Europie. Materiały Międzynarodowej Konferencji. Sandomierz, 13-14 września 1999 r., red. Józef Krukowski, 45-64. Lublin: Towarzystwo Naukowe KUL.

Feliciani, Giorgio. 2006. “L'Applicazione della legge 20 maggio 1985, n. 222. Gli esiti di una ricerca". Diritto Ecclesiastico I/3-4: 455-461.

Feliciani, Giorgio. 2018. „30 lat dobra wspólnego. Referat wygłoszony na Krajowym Sympozjum Delegatów Diecezjalnych „Sovvenire” pt. Partecipazione e corresponsabilità dei fedeli a sostegno di una Chiesa in uscita, Venezia Mestre, 7-9 maja 2018 r." Studia z Prawa Wyznaniowego 21: 391-411.

Ferrari, Silvio. 2007. „Państwo i Kościół we Włoszech”. W: Państwo i Kościót w krajach Unii Europejskiej, ed. Gerhard Robbers, thum. Joanna Łopatowska-Rynkowska, Michał Rynkowski, 391-406. Wrocław: Kolonia Limited.

Finocchiaro, Francesco. 2015. Diritto ecclesiastico. Bologna: Zanichelli editore.

Krukowski, Józef. 2013. „Systemy finansowania Kościołów w świecie współczesnym. Zarys problematyki”. W: Finansowanie Kościołów i innych związów wyznaniowych, red. Paweł Sobczyk, Krzysztof Warchałowski, 343-358. Warszawa: Oficyna Wydawnicza ASPRA-JR.

Misztal, Henryk, Piotr Stanisz. 2009. „Włoski model finansowania związków wyznaniowych". W: Pro bono Reipublicae. Ksiega Jubileuszowa Profesora Michała Pietrzaka, red. Paweł Borecki, Andrzej Czohara, Tadeusz J. Zieliński, 342-355. Warszawa: LexisNexis.

Parisi, Marco. 2015. "Interventi pubblici a sostegno del fenomeno religioso e rispetto della legalità costituzionale. Il sistema dell'otto per mille all'esame della Corte dei Conti". Diritto e Religioni 1: 156-177.

Stanisz, Piotr. 2009. „Perspektywy zmiany systemu finansowania Kościołów i innych związków wyznaniowych w Polsce". Studia z Prawa Wyznaniowego 12: 5-33.

Vegas, Giuseppe. 2004. 'L'Otto per mille a vent'anni dalla revisione del Concordato lateranense". Quaderni di Diritto e Politica Ecclesiasatica 1: 183-198. DOI: $10.1440 / 12288$. 
Vitale, Antonio. 1993. "Dai benefici ecclesiastici agli Istituti per il sostentamento del clero". W: Il nuovo regime giuridico degli enti e dei beni ecclesiastici. Atti del Convegno di studi, Sassari, 5-7 ottobre 1989, red. Annaluisa Casiraghi, 139-158. Milano: Vita e Pensiero.

Witkowski, Zbigniew (tłum. i oprac.). 2004. Konstytucja Republiki Włoskiej. Warszawa: Wydawnictwo Sejmowe.

\section{ZAŁĄCZNIK A}

ANALIZY STATYSTYCZNE DOCHODÓW Z OTTO PER MILLE ORAZ WYBORÓW DOKONYWANYCH PRZEZ PODATNIKÓW -

\section{LATA 2004-2017.}

(Dane zaczerpnięte zostały ze strony Departamentu Finansów

Ministerstwa Ekonomii i Finansów, https://www1.finanze.gov.it/finanze3/stat_8xMilleSerie/ index.php?req_classe $=01$ )

\section{A.1. ZESTAWIENIE WYBORÓW WYRAŹNYCH ORAZ WYBORÓW NIEWYRAŻONYCH PRZEZ PODATNIKÓW}

\begin{tabular}{|l|c|c|c|c|c|c|c|}
\hline \multirow{2}{*}{} & \multicolumn{5}{|c|}{ Rok podatkowy, do którego odnosi się podział } \\
\cline { 2 - 8 } & \multicolumn{2}{|c|}{$\begin{array}{c}\text { Dochody z 2004 r. } \\
\text { rozdzielane w } 2008 \text { r. }\end{array}$} & \multicolumn{2}{c|}{$\begin{array}{c}\text { Dochody z 2005 r. } \\
\text { rozdzielane w } 2009 \text { r. }\end{array}$} & \multicolumn{2}{c|}{$\begin{array}{c}\text { Dochody z 2006 r. } \\
\text { rozdzielane w } 2010 \text { r. }\end{array}$} \\
\cline { 2 - 8 } & Frekwencja & $\%$ & Frekwencja & $\%$ & Frekwencja & $\%$ \\
\hline $\begin{array}{l}\text { Ogólna liczba } \\
\text { podatników }\end{array}$ & 40.092 .941 & & 40.415 .634 & & 40.545 .042 & \\
\hline $\begin{array}{l}\text { Ważne } \\
\text { wybory wyraźne }\end{array}$ & 16.581 .712 & 41,36 & 17.354 .632 & 42,94 & 17.457 .653 & 43,06 \\
\hline Wybory niewyrażone & 23.321 .388 & 58,17 & 22.858 .750 & 56,56 & 22.913 .841 & 56,51 \\
\hline Nieprawidłowości & 189.841 & 0,47 & 202.252 & 0,50 & 173.548 & 0,43 \\
\hline & $\begin{array}{c}\text { Dochody z 2007 r. } \\
\text { rozdzielane w } 2011 \text { r. }\end{array}$ & $\begin{array}{c}\text { Dochody z 2008 r. } \\
\text { rozdzielane w } 2012 \text { r. }\end{array}$ & $\begin{array}{c}\text { Dochody z 2009 r. } \\
\text { rozdzielane w 2013 r. }\end{array}$ \\
\cline { 2 - 8 } & Frekwencja & $\%$ & Frekwencja & $\%$ & Frekwencja & $\%$ \\
\hline $\begin{array}{l}\text { Ogólna liczba } \\
\text { podatników }\end{array}$ & 41.444 .232 & & 41.696 .792 & & 41.504 .041 & \\
\hline $\begin{array}{l}\text { Ważne } \\
\text { wybory wyraźne }\end{array}$ & 17.992 .047 & 43,41 & 18.464 .201 & 44,28 & 18.532 .985 & 44,66 \\
\hline Wybory niewyrażone & 23.302 .390 & 56,23 & 23.073 .652 & 55,34 & 22.794 .992 & 54,92 \\
\hline Nieprawidłowości & 149.795 & 0,36 & 158.939 & 0,38 & 176.064 & 0,42 \\
\hline
\end{tabular}




\begin{tabular}{|l|r|c|r|c|c|c|c|}
\hline \multirow{2}{*}{} & \multicolumn{6}{|c|}{ Rok podatkowy, do którego odnosi się podział } \\
\cline { 2 - 8 } & \multicolumn{2}{|c|}{$\begin{array}{c}\text { Dochody z 2010 r. } \\
\text { rozdzielane w } 2014 \text { r. }\end{array}$} & \multicolumn{2}{c|}{$\begin{array}{c}\text { Dochody z 2011 r. } \\
\text { rozdzielane w } 2015 \text { r. }\end{array}$} & \multicolumn{2}{c|}{$\begin{array}{c}\text { Dochody z 2012 r. } \\
\text { rozdzielane w } 2016 \text { r. }\end{array}$} \\
\cline { 2 - 8 } & Frekwencja & $\%$ & Frekwencja & $\%$ & Frekwencja & $\%$ \\
\hline $\begin{array}{l}\text { Ogólna liczba } \\
\text { podatników }\end{array}$ & 41.499 .535 & & 41.320 .548 & & 41.414 .154 & \\
\hline $\begin{array}{l}\text { Ważne } \\
\text { wybory wyraźne }\end{array}$ & 18.974 .479 & 45,72 & 18.929 .936 & 45,81 & 18.817 .796 & 45,44 \\
\hline Wybory niewyrażone & 22.350 .913 & 53,86 & 22.221 .036 & 53,78 & 22.422 .053 & 54,14 \\
\hline Nieprawidłowości & 174.143 & 0,42 & 169.576 & 0,41 & 174.305 & 0,42 \\
\hline
\end{tabular}

\begin{tabular}{|l|r|c|c|c|c|c|}
\hline & \multicolumn{2}{|c|}{$\begin{array}{c}\text { Dochody z 2013 r. } \\
\text { rozdzielane w } 2017 \text { r. }\end{array}$} & \multicolumn{2}{c|}{$\begin{array}{c}\text { Dochody z 2014 r. } \\
\text { rozdzielane w } 2018 \text { r. }\end{array}$} & \multicolumn{2}{c|}{$\begin{array}{c}\text { Dochody z 2015 r. } \\
\text { rozdzielane w } 2019 \text { r. }\end{array}$} \\
\cline { 2 - 8 } & Frekwencja & \multicolumn{1}{c|}{$\%$} & Frekwencja & \multicolumn{1}{c|}{$\%$} & Frekwencja & $\%$ \\
\hline $\begin{array}{l}\text { Ogólna liczba } \\
\text { podatników }\end{array}$ & 40.989 .567 & & 40.716 .548 & & 40.770 .277 & \\
\hline $\begin{array}{l}\text { Ważne } \\
\text { wybory wyraźne }\end{array}$ & 18.688 .601 & 45,59 & 17.777 .621 & 43,66 & 17.592 .274 & 43,15 \\
\hline Wybory niewyrażone & 22.130 .405 & 53,99 & 22.775 .904 & 55,94 & 23.015 .430 & 56,45 \\
\hline Nieprawidłowości & 170.561 & 0,42 & 163.023 & 0,40 & 162.573 & 0,40 \\
\hline
\end{tabular}

\begin{tabular}{|l|r|r|r|c|}
\hline \multirow{2}{*}{} & \multicolumn{2}{|c|}{$\begin{array}{c}\text { Dochody z 2016 r. } \\
\text { rozdzielane w } 2020 \text { r.** }\end{array}$} & \multicolumn{2}{c|}{$\begin{array}{c}\text { Dochody z 2017 r. } \\
\text { rozdzielane w 2021 r.** }\end{array}$} \\
\cline { 2 - 5 } & Frekwencja & \multicolumn{1}{c|}{$\%$} & Frekwencja & $\%$ \\
\hline $\begin{array}{l}\text { Ogólna liczba } \\
\text { podatników }\end{array}$ & 40.872 .080 & & 41.211 .336 & \\
\hline $\begin{array}{l}\text { Ważne } \\
\text { wybory wyraźne }\end{array}$ & 17.340 .826 & 42,43 & 17.207 .151 & 41,75 \\
\hline Wybory niewyrażone & 23.367 .263 & 57,17 & 23.844 .792 & 57,86 \\
\hline Nieprawidłowości & 163.991 & 0,40 & 159.393 & 0,39 \\
\hline
\end{tabular}

\footnotetext{
** Liczby odnoszace się do wyborów sa prowizoryczne.
} 


\section{A.2. ROZKŁAD WYBORÓW DOKONANYCH PRZEZ PODATNIKÓW} I PRZEKAZANE KWOTY

\begin{tabular}{|c|c|c|c|c|c|}
\hline \multirow[b]{2}{*}{ Beneficjenci } & \multicolumn{5}{|c|}{ Dochody z 2004 r. rozdzielane w 2008 r. } \\
\hline & $\begin{array}{l}\text { Ważne } \\
\text { wybory } \\
\text { wyraźne }\end{array}$ & $\begin{array}{c}\% \text { wyborów } \\
\text { w stosunku } \\
\text { do liczby } \\
\text { podatników }\end{array}$ & $\begin{array}{l}\% \text { w stosunku } \\
\text { do ogólnej } \\
\text { liczby } \\
\text { wyborów }\end{array}$ & Kwoty & $\begin{array}{c}\% \\
\text { wpływów }\end{array}$ \\
\hline Państwo* & 1.259 .425 & 3,14 & 7,60 & 99.956 .287 & 8,94 \\
\hline $\begin{array}{l}\text { Kościół Katolicki-- } \\
\text { zaliczka }\end{array}$ & 14.894 .293 & 37,15 & 89,82 & 928.364 .294 & 83,00 \\
\hline $\begin{array}{l}\text { Kościół Katolicki- } \\
\text { wyrównanie }\end{array}$ & & & & 74.149 .421 & 6,63 \\
\hline $\begin{array}{l}\text { Włoska Unia Chrześ- } \\
\text { cijańskich Kościołów } \\
\text { Adwentystów Dnia } \\
\text { Siódmego }\end{array}$ & 30.332 & 0,08 & 0,18 & 1.860 .449 & 0,17 \\
\hline $\begin{array}{l}\text { Zgromadzenia Boże } \\
\text { we Włoszech }\end{array}$ & 30.612 & 0,08 & 0,18 & 778.226 & 0,07 \\
\hline Stół Waldensów & 264.706 & 0,66 & 1,60 & 6.917 .565 & 0,62 \\
\hline $\begin{array}{l}\text { Kościół } \\
\text { Ewangelicko-Luterań- } \\
\text { ski we Włoszech }\end{array}$ & 41.424 & 0,10 & 0,25 & 2.583 .958 & 0,23 \\
\hline $\begin{array}{l}\text { Związek Włoskich } \\
\text { Gmin Żydowskich }\end{array}$ & 60.920 & 0,15 & 0,37 & 3.824 .257 & 0,34 \\
\hline $\begin{array}{l}\text { Chrześcijańska Unia } \\
\text { Ewangelicko-Bapty- } \\
\text { styczna Włoch }\end{array}$ & & & & & \\
\hline $\begin{array}{l}\text { Kościół Apostolski } \\
\text { we Włoszech }\end{array}$ & & & & & \\
\hline $\begin{array}{l}\text { Święta Archidiecezja } \\
\text { Prawosławna Włoch } \\
\text { i Egzarchat dla Euro- } \\
\text { py Południowej }\end{array}$ & & & & & \\
\hline Włoska Unia Buddyjska & & & & & \\
\hline $\begin{array}{l}\text { Włoska Unia Hin- } \\
\text { duistyczna Sanatana } \\
\text { Dharma Samgha }\end{array}$ & & & & & \\
\hline $\begin{array}{l}\text { Włoski Instytut Bud- } \\
\text { dyjski Soka Gakkai }\end{array}$ & & & & & \\
\hline OGÓŁEM & 16.581 .712 & 41 & 100 & 1.118.434.457 & 100 \\
\hline
\end{tabular}

Kwoty okréślone są w euro.

* W odniesieniu do państwa $w$ tabeli wskazano dochody potencjalnie należne $w$ oparciu o decyzje podatników, to znaczy bez uwzględnienia pomniejszeń przewidzianych w obowiąujących przepisach. 


\begin{tabular}{|c|c|c|c|c|c|}
\hline \multirow[b]{2}{*}{ Beneficjenci } & \multicolumn{5}{|c|}{ Dochody z 2005 r. rozdzielane w 2009 r. } \\
\hline & $\begin{array}{l}\text { Ważne } \\
\text { wybory } \\
\text { wyraźne }\end{array}$ & $\begin{array}{l}\text { \% wyborów } \\
\text { w stosunku } \\
\text { do liczby } \\
\text { podatników }\end{array}$ & $\begin{array}{c}\text { \% w stosunku } \\
\text { do ogólnej } \\
\text { liczby } \\
\text { wyborów }\end{array}$ & Kwoty & $\begin{array}{c}\% \\
\text { wpływów }\end{array}$ \\
\hline Państwo* & 1.940 .464 & 4,80 & 11,18 & 142.539 .116 & 12,64 \\
\hline $\begin{array}{l}\text { Kościół Katolicki- } \\
\text { zaliczka }\end{array}$ & 14.934 .247 & 36,95 & 86,05 & 913.216 .482 & 80,99 \\
\hline $\begin{array}{l}\text { Kościół Katolicki - } \\
\text { wyrównanie }\end{array}$ & & & & 54.322 .060 & 4,82 \\
\hline $\begin{array}{l}\text { Włoska Unia Chrześ- } \\
\text { cijańskich Kościołów } \\
\text { Adwentystów Dnia } \\
\text { Siódmego }\end{array}$ & 30.969 & 0,08 & 0,18 & 1.910 .273 & 0,17 \\
\hline $\begin{array}{l}\text { Zgromadzenia Boże } \\
\text { we Włoszech }\end{array}$ & 32.991 & 0,08 & 0,19 & 875.924 & 0,08 \\
\hline Stół Waldensów & 311.654 & 0,77 & 1,80 & 8.298 .225 & 0,73 \\
\hline $\begin{array}{l}\text { Kościół } \\
\text { Ewangelicko-Luterań- } \\
\text { ski we Włoszech }\end{array}$ & 40.419 & 0,10 & 0,23 & 2.440 .904 & 0,22 \\
\hline $\begin{array}{l}\text { Związek Włoskich } \\
\text { Gmin Żydowskich }\end{array}$ & 63.888 & 0,16 & 0,37 & 3.926 .672 & 0,35 \\
\hline $\begin{array}{l}\text { Chrześcijańska Unia } \\
\text { Ewangelicko-Bapty- } \\
\text { styczna Włoch }\end{array}$ & & & & & \\
\hline $\begin{array}{l}\text { Kościół Apostolski } \\
\text { we Włoszech }\end{array}$ & & & & & \\
\hline $\begin{array}{l}\text { Swięta Archidiecezja } \\
\text { Prawosławna Włoch } \\
\text { i Egzarchat dla Euro- } \\
\text { py Południowej }\end{array}$ & & & & & \\
\hline Włoska Unia Buddyjska & & & & & \\
\hline $\begin{array}{l}\text { Włoska Unia Hin- } \\
\text { duistyczna Sanatana } \\
\text { Dharma Samgha }\end{array}$ & & & & & \\
\hline $\begin{array}{l}\text { Włoski Instytut Bud- } \\
\text { dyjski Soka Gakkai }\end{array}$ & & & & & \\
\hline OGÓŁEM & 17.354 .632 & 43 & 100 & 1.127 .529 .656 & 100 \\
\hline
\end{tabular}

Kwoty określone są w euro.

* W odniesieniu do państwa $w$ tabeli wskazano dochody potencjalnie należne $w$ oparciu o decyzje podatników, to znaczy bez uwzględnienia pomniejszeń przewidzianych w obowiazujących przepisach. 


\begin{tabular}{|c|c|c|c|c|c|}
\hline \multirow[b]{2}{*}{ Beneficjenci } & \multicolumn{5}{|c|}{ Dochody z 2006 r. rozdzielane w 2010 r. } \\
\hline & $\begin{array}{l}\text { Ważne } \\
\text { wybory } \\
\text { wyraźne }\end{array}$ & $\begin{array}{l}\text { \% wyborów } \\
\text { w stosunku } \\
\text { do liczby } \\
\text { podatników }\end{array}$ & $\begin{array}{c}\text { \% w stosunku } \\
\text { do ogólnej } \\
\text { liczby } \\
\text { wyborów }\end{array}$ & Kwoty & $\begin{array}{c}\% \\
\text { wpływów }\end{array}$ \\
\hline Państwo* & 2.086 .884 & 5,15 & 11,95 & 165.560 .776 & 13,21 \\
\hline $\begin{array}{l}\text { Kościół Katolicki - } \\
\text { zaliczka }\end{array}$ & 14.840 .308 & 36,60 & 85,00 & 977.010 .978 & 77,98 \\
\hline $\begin{array}{l}\text { Kościół Katolicki - } \\
\text { wyrównanie }\end{array}$ & & & & 90.021 .557 & 7,18 \\
\hline $\begin{array}{l}\text { Włoska Unia Chrześ- } \\
\text { cijańskich Kościołów } \\
\text { Adwentystów Dnia } \\
\text { Siódmego }\end{array}$ & 30.568 & 0,08 & 0,18 & 1.953 .792 & 0,16 \\
\hline $\begin{array}{l}\text { Zgromadzenia Boże } \\
\text { we Włoszech }\end{array}$ & 34.711 & 0,09 & 0,20 & 999.882 & 0,08 \\
\hline Stół Waldensów & 357.771 & 0,88 & 2,05 & 10.248 .789 & 0,82 \\
\hline $\begin{array}{l}\text { Kościół } \\
\text { Ewangelicko-Luterań- } \\
\text { ski we Włoszech }\end{array}$ & 43.070 & 0,11 & 0,25 & 2.873 .224 & 0,23 \\
\hline $\begin{array}{l}\text { Związek Włoskich } \\
\text { Gmin Żydowskich }\end{array}$ & 64.341 & 0,16 & 0,37 & 4.252 .371 & 0,34 \\
\hline $\begin{array}{l}\text { Chrześcijańska Unia } \\
\text { Ewangelicko-Bapty- } \\
\text { styczna Włoch }\end{array}$ & & & & & \\
\hline $\begin{array}{l}\text { Kościół Apostolski } \\
\text { we Włoszech }\end{array}$ & & & & & \\
\hline $\begin{array}{l}\text { Święta Archidiecezja } \\
\text { Prawosławna Włoch } \\
\text { i Egzarchat dla Euro- } \\
\text { py Południowej }\end{array}$ & & & & & \\
\hline Włoska Unia Buddyjska & & & & & \\
\hline $\begin{array}{l}\text { Włoska Unia Hin- } \\
\text { duistyczna Sanatana } \\
\text { Dharma Samgha }\end{array}$ & & & & & \\
\hline $\begin{array}{l}\text { Włoski Instytut Bud- } \\
\text { dyjski Soka Gakkai }\end{array}$ & & & & & \\
\hline OGÓŁEM & 17.457 .653 & 43 & 100 & 1.252 .921 .369 & 100 \\
\hline
\end{tabular}

Kwoty określone są w euro.

* W odniesieniu do państwa $w$ tabeli wskazano dochody potencjalnie należne $w$ oparciu o decyzje podatników, to znaczy bez uwzględnienia pomniejszeń przewidzianych w obowiazujących przepisach. 


\begin{tabular}{|c|c|c|c|c|c|}
\hline \multirow[b]{2}{*}{ Beneficjenci } & \multicolumn{5}{|c|}{ Dochody z 2007 r. rozdzielane w 2011 r. } \\
\hline & $\begin{array}{l}\text { Ważne } \\
\text { wybory } \\
\text { wyraźne }\end{array}$ & $\begin{array}{c}\% \text { wyborów } \\
\text { w stosunku } \\
\text { do liczby } \\
\text { podatników }\end{array}$ & $\begin{array}{c}\% \text { w stosunku } \\
\text { do ogólnej } \\
\text { liczby } \\
\text { wyborów }\end{array}$ & Kwoty & $\begin{array}{c}\% \\
\text { wpływów }\end{array}$ \\
\hline Państwo* & 2.096 .814 & 5,06 & 11,65 & 174.251 .950 & 13,24 \\
\hline $\begin{array}{l}\text { Kościół Katolicki - } \\
\text { zaliczka }\end{array}$ & 15.294 .285 & 36,90 & 85,02 & 1.023 .520 .919 & 77,77 \\
\hline $\begin{array}{l}\text { Kościół Katolicki - } \\
\text { wyrównanie }\end{array}$ & & & & 95.156 .625 & 7,23 \\
\hline $\begin{array}{l}\text { Włoska Unia Chrześ- } \\
\text { cijańskich Kościołów } \\
\text { Adwentystów Dnia } \\
\text { Siódmego }\end{array}$ & 31.992 & 0,08 & 0,18 & 2.167 .201 & 0,16 \\
\hline $\begin{array}{l}\text { Zgromadzenia Boże } \\
\text { we Włoszech }\end{array}$ & 36.863 & 0,09 & 0,20 & 1.106 .681 & 0,08 \\
\hline Stół Waldensów & 414.365 & 1,00 & 2,30 & 12.120 .795 & 0,92 \\
\hline $\begin{array}{l}\text { Kościół } \\
\text { Ewangelicko-Luterań- } \\
\text { ski we Włoszech }\end{array}$ & 47.423 & 0,11 & 0,26 & 3.130 .402 & 0,24 \\
\hline $\begin{array}{l}\text { Związek Włoskich } \\
\text { Gmin Żydowskich }\end{array}$ & 70.305 & 0,17 & 0,39 & 4.695 .602 & 0,36 \\
\hline $\begin{array}{l}\text { Chrześcijańska Unia } \\
\text { Ewangelicko-Bapty- } \\
\text { styczna Włoch }\end{array}$ & & & & & \\
\hline $\begin{array}{l}\text { Kościół Apostolski } \\
\text { we Włoszech }\end{array}$ & & & & & \\
\hline $\begin{array}{l}\text { Święta Archidiecezja } \\
\text { Prawosławna Włoch } \\
\text { i Egzarchat dla Euro- } \\
\text { py Południowej }\end{array}$ & & & & & \\
\hline Włoska Unia Buddyjska & & & & & \\
\hline $\begin{array}{l}\text { Włoska Unia Hin- } \\
\text { duistyczna Sanatana } \\
\text { Dharma Samgha }\end{array}$ & & & & & \\
\hline $\begin{array}{l}\text { Włoski Instytut Bud- } \\
\text { dyjski Soka Gakkai }\end{array}$ & & & & & \\
\hline OGÓŁEM & 17.992 .047 & 43 & 100 & 1.316 .150 .175 & 100 \\
\hline
\end{tabular}

Kwoty określone są w euro.

* W odniesieniu do państwa $w$ tabeli wskazano dochody potencjalnie należne $w$ oparciu o decyzje podatników, to znaczy bez uwzględnienia pomniejszeń przewidzianych w obowiazujących przepisach. 


\begin{tabular}{|c|c|c|c|c|c|}
\hline \multirow[b]{2}{*}{ Beneficjenci } & \multicolumn{5}{|c|}{ Dochody z 2008 r. rozdzielane w 2012 r. } \\
\hline & $\begin{array}{l}\text { Ważne } \\
\text { wybory } \\
\text { wyraźne }\end{array}$ & $\begin{array}{l}\% \text { wyborów } \\
\text { w stosunku } \\
\text { do liczby } \\
\text { podatników }\end{array}$ & $\begin{array}{c}\% \text { w stosunku } \\
\text { do ogólnej } \\
\text { liczby } \\
\text { wyborów }\end{array}$ & Kwoty & $\begin{array}{c}\% \\
\text { wpływów }\end{array}$ \\
\hline Państwo* & 2.492 .645 & 5,98 & 13,50 & 205.765 .971 & 14,92 \\
\hline $\begin{array}{l}\text { Kościół Katolicki - } \\
\text { zaliczka }\end{array}$ & 15.310 .750 & 36,72 & 82,92 & 1.030 .646 .538 & 74,72 \\
\hline $\begin{array}{l}\text { Kościół Katolicki- } \\
\text { wyrównanie }\end{array}$ & & & & 117.430 .056 & 8,51 \\
\hline $\begin{array}{l}\text { Włoska Unia Chrześ- } \\
\text { cijańskich Kościołów } \\
\text { Adwentystów Dnia } \\
\text { Siódmego }\end{array}$ & 31.349 & 0,08 & 0,17 & 2.112 .999 & 0,15 \\
\hline $\begin{array}{l}\text { Zgromadzenia Boże } \\
\text { we Włoszech }\end{array}$ & 39.579 & 0,09 & 0,21 & 1.165 .704 & 0,09 \\
\hline Stół Waldensów & 470.225 & 1,13 & 2,55 & 14.154 .983 & 1,03 \\
\hline $\begin{array}{l}\text { Kościół } \\
\text { Ewangelicko-Luterań- } \\
\text { ski we Włoszech }\end{array}$ & 49.233 & 0,12 & 0,27 & 3.355 .940 & 0,24 \\
\hline $\begin{array}{l}\text { Związek Włoskich } \\
\text { Gmin Żydowskich }\end{array}$ & 70.420 & 0,17 & 0,38 & 4.723 .175 & 0,34 \\
\hline $\begin{array}{l}\text { Chrześcijańska Unia } \\
\text { Ewangelicko-Bapty- } \\
\text { styczna Włoch }\end{array}$ & & & & & \\
\hline $\begin{array}{l}\text { Kościół Apostolski } \\
\text { we Włoszech }\end{array}$ & & & & & \\
\hline $\begin{array}{l}\text { Święta Archidiecezja } \\
\text { Prawosławna Włoch } \\
\text { i Egzarchat dla Euro- } \\
\text { py Południowej }\end{array}$ & & & & & \\
\hline Włoska Unia Buddyjska & & & & & \\
\hline $\begin{array}{l}\text { Włoska Unia Hin- } \\
\text { duistyczna Sanatana } \\
\text { Dharma Samgha }\end{array}$ & & & & & \\
\hline $\begin{array}{l}\text { Włoski Instytut Bud- } \\
\text { dyjski Soka Gakkai }\end{array}$ & & & & & \\
\hline OGÓŁEM & 18.464 .201 & 44 & 100 & 1.379 .355 .366 & 100 \\
\hline
\end{tabular}

Kwoty określone są w euro.

* W odniesieniu do państwa w tabeli wskazano dochody potencjalnie należne w oparciu o decyzje podatników, to znaczy bez uwzględnienia pomniejszeń przewidzianych w obowiąujących przepisach. 


\begin{tabular}{|c|c|c|c|c|c|}
\hline \multirow[b]{2}{*}{ Beneficjenci } & \multicolumn{5}{|c|}{ Dochody z 2009 r. rozdzielane w 2013 r. } \\
\hline & $\begin{array}{l}\text { Ważne } \\
\text { wybory } \\
\text { wyraźne }\end{array}$ & $\begin{array}{c}\% \text { wyborów } \\
\text { w stosunku } \\
\text { do liczby } \\
\text { podatników }\end{array}$ & $\begin{array}{c}\% \text { w stosunku } \\
\text { do ogólnej } \\
\text { liczby } \\
\text { wyborów }\end{array}$ & Kwoty & $\begin{array}{c}\% \\
\text { wpływów }\end{array}$ \\
\hline Państwo* & 2.547 .300 & 6,14 & 13,74 & 192.172 .518 & 15,07 \\
\hline $\begin{array}{l}\text { Kościół Katolicki - } \\
\text { zaliczka }\end{array}$ & 15.198 .625 & 36,62 & 82,01 & 1.004 .839 .287 & 78,79 \\
\hline $\begin{array}{l}\text { Kościół Katolicki - } \\
\text { wyrównanie }\end{array}$ & & & & 27.828 .310 & 2,18 \\
\hline $\begin{array}{l}\text { Włoska Unia Chrześ- } \\
\text { cijańskich Kościołów } \\
\text { Adwentystów Dnia } \\
\text { Siódmego }\end{array}$ & 34.774 & 0,08 & 0,19 & 2.328 .002 & 0,18 \\
\hline $\begin{array}{l}\text { Zgromadzenia Boże } \\
\text { we Włoszech }\end{array}$ & 43.445 & 0,10 & 0,23 & 1.270 .403 & 0,10 \\
\hline Stół Waldensów & 570.415 & 1,37 & 3,08 & 37.738 .142 & 2,96 \\
\hline $\begin{array}{l}\text { Kościół } \\
\text { Ewangelicko-Luterań- } \\
\text { ski we Włoszech }\end{array}$ & 58.566 & 0,14 & 0,32 & 3.920 .846 & 0,31 \\
\hline $\begin{array}{l}\text { Związek Włoskich } \\
\text { Gmin Żydowskich }\end{array}$ & 79.860 & 0,19 & 0,43 & 5.268 .637 & 0,41 \\
\hline $\begin{array}{l}\text { Chrześcijańska Unia } \\
\text { Ewangelicko-Bapty- } \\
\text { styczna Włoch }\end{array}$ & & & & & \\
\hline $\begin{array}{l}\text { Kościół Apostolski } \\
\text { we Włoszech }\end{array}$ & & & & & \\
\hline $\begin{array}{l}\text { Święta Archidiecezja } \\
\text { Prawosławna Włoch } \\
\text { i Egzarchat dla Euro- } \\
\text { py Południowej }\end{array}$ & & & & & \\
\hline Włoska Unia Buddyjska & & & & & \\
\hline $\begin{array}{l}\text { Włoska Unia Hin- } \\
\text { duistyczna Sanatana } \\
\text { Dharma Samgha }\end{array}$ & & & & & \\
\hline $\begin{array}{l}\text { Włoski Instytut Bud- } \\
\text { dyjski Soka Gakkai }\end{array}$ & & & & & \\
\hline OGÓŁEM & 18.532 .985 & 45 & 100 & 1.275 .366 .145 & 100 \\
\hline
\end{tabular}

Kwoty określone są w euro.

* W odniesieniu do państwa w tabeli wskazano dochody potencjalnie należne w oparciu o decyzje podatników, to znaczy bez uwzględnienia pomniejszeń przewidzianych w obowiązujacych przepisach. 


\begin{tabular}{|c|c|c|c|c|c|}
\hline \multirow[b]{2}{*}{ Beneficjenci } & \multicolumn{5}{|c|}{ Dochody z 2010 r. rozdzielane w 2014 r. } \\
\hline & $\begin{array}{l}\text { Ważne } \\
\text { wybory } \\
\text { wyraźne }\end{array}$ & $\begin{array}{l}\% \text { wyborów } \\
\text { w stosunku } \\
\text { do liczby } \\
\text { podatników }\end{array}$ & $\begin{array}{c}\% \text { w stosunku } \\
\text { do ogólnej } \\
\text { liczby } \\
\text { wyborów }\end{array}$ & Kwoty & $\begin{array}{c}\% \\
\text { wpływów }\end{array}$ \\
\hline Państwo* & 2.533 .222 & 6,10 & 13,35 & 170.347 .958 & 13,32 \\
\hline $\begin{array}{l}\text { Kościół Katolicki - } \\
\text { zaliczka }\end{array}$ & 15.604 .034 & 37,60 & 82,24 & 1.038 .915 .810 & 81,25 \\
\hline $\begin{array}{l}\text { Kościół Katolicki- } \\
\text { wyrównanie }\end{array}$ & & & & 15.394 .892 & 1,20 \\
\hline $\begin{array}{l}\text { Włoska Unia Chrześ- } \\
\text { cijańskich Kościołów } \\
\text { Adwentystów Dnia } \\
\text { Siódmego }\end{array}$ & 34.793 & 0,08 & 0,18 & 2.273 .892 & 0,18 \\
\hline $\begin{array}{l}\text { Zgromadzenia Boże } \\
\text { we Włoszech }\end{array}$ & 46.740 & 0,11 & 0,25 & 1.457 .185 & 0,11 \\
\hline Stół Waldensów & 613.002 & 1,48 & 3,23 & 40.803 .722 & 3,19 \\
\hline $\begin{array}{l}\text { Kościół } \\
\text { Ewangelicko-Luterań- } \\
\text { ski we Włoszech }\end{array}$ & 61.231 & 0,15 & 0,32 & 4.042 .474 & 0,32 \\
\hline $\begin{array}{l}\text { Związek Włoskich } \\
\text { Gmin Żydowskich }\end{array}$ & 81.457 & 0,20 & 0,43 & 5.432 .074 & 0,43 \\
\hline $\begin{array}{l}\text { Chrześcijańska Unia } \\
\text { Ewangelicko-Bapty- } \\
\text { styczna Włoch }\end{array}$ & & & & & \\
\hline $\begin{array}{l}\text { Kościół Apostolski } \\
\text { we Włoszech }\end{array}$ & & & & & \\
\hline $\begin{array}{l}\text { Święta Archidiecezja } \\
\text { Prawosławna Włoch } \\
\text { i Egzarchat dla Euro- } \\
\text { py Południowej }\end{array}$ & & & & & \\
\hline Włoska Unia Buddyjska & & & & & \\
\hline $\begin{array}{l}\text { Włoska Unia Hin- } \\
\text { duistyczna Sanatana } \\
\text { Dharma Samgha }\end{array}$ & & & & & \\
\hline $\begin{array}{l}\text { Włoski Instytut Bud- } \\
\text { dyjski Soka Gakkai }\end{array}$ & & & & & \\
\hline OGÓŁEM & 18.974 .479 & 46 & 100 & 1.278 .668 .007 & 100 \\
\hline
\end{tabular}

Kwoty określone są w euro.

* W odniesieniu do państwa w tabeli wskazano dochody potencjalnie należne w oparciu o decyzje podatników, to znaczy bez uwzględnienia pomniejszeń przewidzianych w obowiązujących przepisach. 


\begin{tabular}{|c|c|c|c|c|c|}
\hline \multirow[b]{2}{*}{ Beneficjenci } & \multicolumn{5}{|c|}{ Dochody z 2011 r. rozdzielane w 2015 r. } \\
\hline & $\begin{array}{l}\text { Ważne } \\
\text { wybory } \\
\text { wyraźne }\end{array}$ & $\begin{array}{l}\text { \% wyborów } \\
\text { w stosunku } \\
\text { do liczby } \\
\text { podatników }\end{array}$ & $\begin{array}{l}\text { \% w stosunku } \\
\text { do ogólnej } \\
\text { liczby } \\
\text { wyborów }\end{array}$ & Kwoty & $\begin{array}{c}\% \\
\text { wpływów }\end{array}$ \\
\hline Państwo* & 2.904 .884 & 7,03 & 15,35 & 195.612 .564 & 15,71 \\
\hline $\begin{array}{l}\text { Kościół Katolicki - } \\
\text { zaliczka }\end{array}$ & 15.185 .809 & 36,75 & 80,22 & 1.013 .054 .493 & 79,94 \\
\hline $\begin{array}{l}\text { Kościół Katolicki - } \\
\text { wyrównanie }\end{array}$ & & & & -17.592 .045 & \\
\hline $\begin{array}{l}\text { Włoska Unia Chrześ- } \\
\text { cijańskich Kościołów } \\
\text { Adwentystów Dnia } \\
\text { Siódmego }\end{array}$ & 35.119 & 0,08 & 0,19 & 2.399 .406 & 0,19 \\
\hline $\begin{array}{l}\text { Zgromadzenia Boże } \\
\text { we Włoszech }\end{array}$ & 48.900 & 0,12 & 0,26 & 1.517 .586 & 0,12 \\
\hline Stół Waldensów & 604.345 & 1,46 & 3,19 & 40.284 .765 & 3,24 \\
\hline $\begin{array}{l}\text { Kościół } \\
\text { Ewangelicko-Luterań- } \\
\text { ski we Włoszech }\end{array}$ & 63.378 & 0,15 & 0,33 & 4.167.389 & 0,33 \\
\hline $\begin{array}{l}\text { Związek Włoskich } \\
\text { Gmin Żydowskich }\end{array}$ & 87.510 & 0,21 & 0,46 & 5.809 .088 & 0,47 \\
\hline $\begin{array}{l}\text { Chrześcijańska Unia } \\
\text { Ewangelicko-Bapty- } \\
\text { styczna Włoch }\end{array}$ & & & & & \\
\hline $\begin{array}{l}\text { Kościół Apostolski } \\
\text { we Włoszech }\end{array}$ & & & & & \\
\hline $\begin{array}{l}\text { Święta Archidiecezja } \\
\text { Prawosławna Włoch } \\
\text { i Egzarchat dla Euro- } \\
\text { py Południowej }\end{array}$ & & & & & \\
\hline Włoska Unia Buddyjska & & & & & \\
\hline $\begin{array}{l}\text { Włoska Unia Hin- } \\
\text { duistyczna Sanatana } \\
\text { Dharma Samgha }\end{array}$ & & & & & \\
\hline $\begin{array}{l}\text { Włoski Instytut Bud- } \\
\text { dyjski Soka Gakkai }\end{array}$ & & & & & \\
\hline OGÓŁEM & 18.929 .945 & 46 & 100 & 1.245 .253 .247 & 100 \\
\hline
\end{tabular}

Kwoty określone są w euro.

* W odniesieniu do państwa w tabeli wskazano dochody potencjalnie należne w oparciu o decyzje podatników, to znaczy bez uwzględnienia pomniejszeń przewidzianych w obowiązujących przepisach. 


\begin{tabular}{|c|c|c|c|c|c|}
\hline \multirow[b]{2}{*}{ Beneficjenci } & \multicolumn{5}{|c|}{ Dochody z 2012 r. rozdzielane w 2016 r. } \\
\hline & $\begin{array}{l}\text { Ważne } \\
\text { wybory } \\
\text { wyraźne }\end{array}$ & $\begin{array}{l}\% \text { wyborów } \\
\text { w stosunku } \\
\text { do liczby } \\
\text { podatników }\end{array}$ & $\begin{array}{c}\% \text { w stosunku } \\
\text { do ogólnej } \\
\text { liczby } \\
\text { wyborów }\end{array}$ & Kwoty & $\begin{array}{c}\% \\
\text { wpływów }\end{array}$ \\
\hline Państwo* & 2.786 .279 & 6,73 & 14,81 & 187.173 .782 & 14,88 \\
\hline $\begin{array}{l}\text { Kościół Katolicki - } \\
\text { zaliczka }\end{array}$ & 15.226 .291 & 36,77 & 80,91 & 1.011.841.026 & 80,46 \\
\hline $\begin{array}{l}\text { Kościół Katolicki- } \\
\text { wyrównanie }\end{array}$ & & & & 7.001 .740 & 0,56 \\
\hline $\begin{array}{l}\text { Włoska Unia Chrześ- } \\
\text { cijańskich Kościołów } \\
\text { Adwentystów Dnia } \\
\text { Siódmego }\end{array}$ & 29.448 & 0,07 & 0,16 & 2.000 .922 & 0,16 \\
\hline $\begin{array}{l}\text { Zgromadzenia Boże } \\
\text { we Włoszech }\end{array}$ & 44.229 & 0,11 & 0,24 & 1.376 .434 & 0,11 \\
\hline Stół Waldensów & 562.313 & 1,36 & 2,99 & 37.392 .222 & 2,97 \\
\hline $\begin{array}{l}\text { Kościół } \\
\text { Ewangelicko-Luterań- } \\
\text { ski we Włoszech }\end{array}$ & 47.859 & 0,12 & 0,25 & 3.126 .440 & 0,25 \\
\hline $\begin{array}{l}\text { Związek Włoskich } \\
\text { Gmin Żydowskich }\end{array}$ & 72.238 & 0,17 & 0,38 & 4.752 .189 & 0,38 \\
\hline $\begin{array}{l}\text { Chrześcijańska Unia } \\
\text { Ewangelicko-Bapty- } \\
\text { styczna Włoch }\end{array}$ & 16.407 & 0,04 & 0,09 & 1.125 .518 & 0,09 \\
\hline $\begin{array}{l}\text { Kościół Apostolski } \\
\text { we Włoszech }\end{array}$ & 9.597 & 0,02 & 0,05 & 286.757 & 0,02 \\
\hline $\begin{array}{l}\text { Święta Archidiecezja } \\
\text { Prawosławna Włoch } \\
\text { i Egzarchat dla Euro- } \\
\text { py Południowej }\end{array}$ & 23.135 & 0,06 & 0,12 & 1.500 .691 & 0,12 \\
\hline Włoska Unia Buddyjska & & & & & \\
\hline $\begin{array}{l}\text { Włoska Unia Hin- } \\
\text { duistyczna Sanatana } \\
\text { Dharma Samgha }\end{array}$ & & & & & \\
\hline $\begin{array}{l}\text { Włoski Instytut Bud- } \\
\text { dyjski Soka Gakkai }\end{array}$ & & & & & \\
\hline OGÓŁEM & 18.817 .796 & 45 & 100 & 1.257 .577 .721 & 100 \\
\hline
\end{tabular}

Kwoty określone sa w euro.

* W odniesieniu do państwa $w$ tabeli wskazano dochody potencjalnie należne $w$ oparciu o decyzje podatników, to znaczy bez uwzględnienia pomniejszeń przewidzianych w obowiazujących przepisach. 


\begin{tabular}{|c|c|c|c|c|c|}
\hline \multirow[b]{2}{*}{ Beneficjenci } & \multicolumn{5}{|c|}{ Dochody z 2013 r. rozdzielane w 2017 r. } \\
\hline & $\begin{array}{l}\text { Ważne } \\
\text { wybory } \\
\text { wyraźne }\end{array}$ & $\begin{array}{l}\text { \% wyborów } \\
\text { w stosunku } \\
\text { do liczby } \\
\text { podatników }\end{array}$ & $\mid \begin{array}{c}\% \text { w stosunku } \\
\text { do ogólnej } \\
\text { liczby } \\
\text { wyborów }\end{array}$ & Kwoty & $\begin{array}{c}\% \\
\text { wpływów }\end{array}$ \\
\hline Państwo* & 2.685 .883 & 6,55 & 14,37 & 181.066 .782 & 14,53 \\
\hline $\begin{array}{l}\text { Kościół Katolicki - } \\
\text { zaliczka }\end{array}$ & 15.180 .978 & 37,04 & 81,23 & 1.038 .915 .810 & 81,23 \\
\hline $\begin{array}{l}\text { Kościół Katolicki - } \\
\text { wyrównanie }\end{array}$ & & & & -26.422 .586 & \\
\hline $\begin{array}{l}\text { Włoska Unia Chrześ- } \\
\text { cijańskich Kościołów } \\
\text { Adwentystów Dnia } \\
\text { Siódmego }\end{array}$ & 25.699 & 0,06 & 0,14 & 1.745 .033 & 0,14 \\
\hline $\begin{array}{l}\text { Zgromadzenia Boże } \\
\text { we Włoszech }\end{array}$ & 43.640 & 0,11 & 0,23 & 1.319 .033 & 0,11 \\
\hline Stół Waldensów & 514.628 & 1,26 & 2,75 & 34.277 .439 & 2,75 \\
\hline $\begin{array}{l}\text { Kościół } \\
\text { Ewangelicko-Luterań- } \\
\text { ski we Włoszech }\end{array}$ & 37.062 & 0,09 & 0,20 & 2.492 .905 & 0,20 \\
\hline $\begin{array}{l}\text { Związek Włoskich } \\
\text { Gmin Żydowskich }\end{array}$ & 61.310 & 0,15 & 0,33 & 4.113 .293 & 0,33 \\
\hline $\begin{array}{l}\text { Chrześcijańska Unia } \\
\text { Ewangelicko-Bapty- } \\
\text { styczna Włoch }\end{array}$ & 13.396 & 0,03 & 0,07 & 872.517 & 0,07 \\
\hline $\begin{array}{l}\text { Kościół Apostolski } \\
\text { we Włoszech }\end{array}$ & 10.307 & 0,03 & 0,06 & 344.096 & 0,03 \\
\hline $\begin{array}{l}\text { Święta Archidiecezja } \\
\text { Prawosławna Włoch } \\
\text { i Egzarchat dla Euro- } \\
\text { py Południowej }\end{array}$ & 22.483 & 0,05 & 0,12 & 1.495 .743 & 0,12 \\
\hline Włoska Unia Buddyjska & 71.997 & 0,17 & 0,39 & 4.861 .164 & 0,39 \\
\hline $\begin{array}{l}\text { Włoska Unia Hin- } \\
\text { duistyczna Sanatana } \\
\text { Dharma Samgha }\end{array}$ & 21.218 & 0,05 & 0,11 & 1.371 .098 & 0,11 \\
\hline $\begin{array}{l}\text { Włoski Instytut Bud- } \\
\text { dyjski Soka Gakkai }\end{array}$ & & & & & \\
\hline OGÓŁEM & 18.688 .601 & 46 & 100 & 1.246 .452 .327 & 100 \\
\hline
\end{tabular}

Kwoty określone są w euro.

* W odniesieniu do państwa $w$ tabeli wskazano dochody potencjalnie należne $w$ oparciu o decyzje podatników, to znaczy bez uwzględnienia pomniejszeń przewidzianych w obowiąujacych przepisach. 


\begin{tabular}{|c|c|c|c|c|c|}
\hline \multirow[b]{2}{*}{ Beneficjenci } & \multicolumn{5}{|c|}{ Dochody z 2014 r. rozdzielane w 2018 r.** } \\
\hline & $\begin{array}{l}\text { Ważne } \\
\text { wybory } \\
\text { wyraźne }\end{array}$ & $\begin{array}{l}\% \text { wyborów } \\
\text { w stosunku } \\
\text { do liczby } \\
\text { podatników }\end{array}$ & $\begin{array}{c}\% \text { w stosunku } \\
\text { do ogólnej } \\
\text { liczby } \\
\text { wyborów }\end{array}$ & Kwoty & $\begin{array}{c}\% \\
\text { wpływów }\end{array}$ \\
\hline Państwo* & 2.493 .431 & 6,12 & 14,03 & 175.632 .294 & 14,28 \\
\hline $\begin{array}{l}\text { Kościół Katolicki- } \\
\text { zaliczka }\end{array}$ & 14.437 .694 & 35,46 & 81,21 & 1.005.390.045 & 81,09 \\
\hline $\begin{array}{l}\text { Kościół Katolicki- } \\
\text { wyrównanie }\end{array}$ & & & & -7.664 .448 & \\
\hline $\begin{array}{l}\text { Włoska Unia Chrześ- } \\
\text { cijańskich Kościołów } \\
\text { Adwentystów Dnia } \\
\text { Siódmego }\end{array}$ & 23.711 & 0,06 & 0,13 & 1.609 .416 & 0,13 \\
\hline $\begin{array}{l}\text { Zgromadzenia Boże } \\
\text { we Włoszech }\end{array}$ & 40.496 & 0,10 & 0,23 & 1.254 .577 & 0,10 \\
\hline Stół Waldensów & 469.071 & 1,15 & 2,64 & 32.683 .533 & 2,66 \\
\hline $\begin{array}{l}\text { Kościół } \\
\text { Ewangelicko-Luterań- } \\
\text { ski we Włoszech }\end{array}$ & 64.882 & 0,16 & 0,36 & 4.456 .845 & 0,36 \\
\hline $\begin{array}{l}\text { Związek Włoskich } \\
\text { Gmin Żydowskich }\end{array}$ & 56.937 & 0,14 & 0,32 & 3.961 .640 & 0,32 \\
\hline $\begin{array}{l}\text { Chrześcijańska Unia } \\
\text { Ewangelicko-Bapty- } \\
\text { styczna Włoch }\end{array}$ & 14.166 & 0,03 & 0,08 & 990.410 & 0,08 \\
\hline $\begin{array}{l}\text { Kościół Apostolski } \\
\text { we Włoszech }\end{array}$ & 8.991 & 0,02 & 0,05 & 272.734 & 0,02 \\
\hline $\begin{array}{l}\text { Święta Archidiecezja } \\
\text { Prawosławna Włoch } \\
\text { i Egzarchat dla Euro- } \\
\text { py Południowej }\end{array}$ & 25.475 & 0,06 & 0,14 & 1.733 .218 & 0,14 \\
\hline Włoska Unia Buddyjska & 125.786 & 0,31 & 0,71 & 8.789 .890 & 0,71 \\
\hline $\begin{array}{l}\text { Włoska Unia Hin- } \\
\text { duistyczna Sanatana } \\
\text { Dharma Samgha }\end{array}$ & 16.981 & 0,04 & 0,10 & 1.238 .013 & 0,10 \\
\hline $\begin{array}{l}\text { Włoski Instytut Bud- } \\
\text { dyjski Soka Gakkai }\end{array}$ & & & & & \\
\hline OGÓŁEM & 17.777 .621 & 44 & 100 & 1.230 .348 .167 & 100 \\
\hline
\end{tabular}

Kwoty określone są w euro.

* W odniesieniu do państwa $w$ tabeli wskazano dochody potencjalnie należne $w$ oparciu o decyzje podatników, to znaczy bez uwzględnienia pomniejszeń przewidzianych w obowiazujacych przepisach.

** W odniesieniu do tego roku stwierdzono a posteriori pewne błędy popetnione przez jedno z Centrów Poradnictwa Podatkowego (Caf) we wskazaniach, majacych znaczenie krajowe, które faworyzowaty Kościót Ewangelicko-Luterański (prawidłowy odsetek wynosi 0,18\%, a nie 0,36\%), z niekorzyścią dla Ewangelickiego Kościoła Waldensów (prawidtowy odsetek wynosi 2,82\%, a nie 2,64\%), odnosząc się do kwoty 2.228.422,70 euro. Procedura wyrównania kwot jest w toku. 


\begin{tabular}{|c|c|c|c|c|c|}
\hline \multirow[b]{2}{*}{ Beneficjenci } & \multicolumn{5}{|c|}{ Dochody z 2015 r. rozdzielane w 2019 r. } \\
\hline & $\begin{array}{l}\text { Ważne } \\
\text { wybory } \\
\text { wyraźne }\end{array}$ & $\begin{array}{c}\% \text { wyborów } \\
\text { w stosunku } \\
\text { do liczby } \\
\text { podatników }\end{array}$ & $\begin{array}{c}\% \text { w stosunku } \\
\text { do ogólnej } \\
\text { liczby } \\
\text { wyborów }\end{array}$ & Kwoty & $\begin{array}{c}\% \\
\text { wpływów }\end{array}$ \\
\hline Państwo* & 2.564 .290 & 6,29 & 14,58 & 197.722 .621 & 14,11 \\
\hline $\begin{array}{l}\text { Kościół Katolicki - } \\
\text { zaliczka }\end{array}$ & 14.050 .748 & 34,46 & 79,87 & 1.071.518.621 & 80,73 \\
\hline $\begin{array}{l}\text { Kościół Katolicki - } \\
\text { wyrównanie }\end{array}$ & & & & 59.677 .595 & \\
\hline $\begin{array}{l}\text { Włoska Unia Chrześ- } \\
\text { cijańskich Kościołów } \\
\text { Adwentystów Dnia } \\
\text { Siódmego }\end{array}$ & 23.999 & 0,06 & 0,14 & 1.878 .210 & 0,13 \\
\hline $\begin{array}{l}\text { Zgromadzenia Boże } \\
\text { we Włoszech }\end{array}$ & 41.235 & 0,10 & 0,23 & 1.343 .792 & 0,10 \\
\hline Stół Waldensów & 565.760 & 1,39 & 3,22 & 43.198 .823 & 3,08 \\
\hline $\begin{array}{l}\text { Kościół } \\
\text { Ewangelicko-Luterań- } \\
\text { ski we Włoszech }\end{array}$ & 30.187 & 0,07 & 0,17 & 2.280 .683 & 0,16 \\
\hline $\begin{array}{l}\text { Związek Włoskich } \\
\text { Gmin Żydowskich }\end{array}$ & 60.160 & 0,15 & 0,34 & 4.561 .366 & 0,33 \\
\hline $\begin{array}{l}\text { Chrześcijańska Unia } \\
\text { Ewangelicko-Bapty- } \\
\text { styczna Włoch }\end{array}$ & 16.472 & 0,04 & 0,09 & 1.207 .421 & 0,09 \\
\hline $\begin{array}{l}\text { Kościół Apostolski } \\
\text { we Włoszech }\end{array}$ & 9.647 & 0,02 & 0,05 & 292.129 & 0,02 \\
\hline $\begin{array}{l}\text { Święta Archidiecezja } \\
\text { Prawosławna Włoch } \\
\text { i Egzarchat dla Euro- } \\
\text { py Południowej }\end{array}$ & 31.623 & 0,08 & 0,18 & 2.414 .841 & 0,17 \\
\hline Włoska Unia Buddyjska & 176.858 & 0,43 & 1,01 & 13.549 .941 & 0,97 \\
\hline $\begin{array}{l}\text { Włoska Unia Hin- } \\
\text { duistyczna Sanatana } \\
\text { Dharma Samgha }\end{array}$ & 21.295 & 0,05 & 0,12 & 1.609 .894 & 0,11 \\
\hline $\begin{array}{l}\text { Włoski Instytut Bud- } \\
\text { dyjski Soka Gakkai }\end{array}$ & & & & & \\
\hline OGÓŁEM & 17.592 .274 & 43 & 100 & 1.401 .255 .936 & 100 \\
\hline
\end{tabular}

Kwoty określone sa w euro.

* W odniesieniu do państwa $w$ tabeli wskazano dochody potencjalnie należne $w$ oparciu o decyzje podatników, to znaczy bez uwzględnienia pomniejszeń przewidzianych w obowiazujących przepisach. 


\begin{tabular}{|c|c|c|c|c|c|}
\hline \multirow[b]{2}{*}{ Beneficjenci } & \multicolumn{5}{|c|}{ Dochody z 2016 r. rozdzielane w 2020 r.*** } \\
\hline & $\begin{array}{l}\text { Ważne } \\
\text { wybory } \\
\text { wyraźne }\end{array}$ & $\begin{array}{l}\% \text { wyborów } \\
\text { w stosunku } \\
\text { do liczby } \\
\text { podatników }\end{array}$ & $\begin{array}{c}\text { \% w stosunku } \\
\text { do ogólnej } \\
\text { liczby } \\
\text { wyborów }\end{array}$ & Kwoty & $\begin{array}{c}\% \\
\text { wpływów }\end{array}$ \\
\hline Państwo* & 2.576 .882 & 6,30 & 14,86 & & \\
\hline $\begin{array}{l}\text { Kościół Katolicki- } \\
\text { zaliczka }\end{array}$ & 13.762 .498 & 33,67 & 79,36 & & \\
\hline $\begin{array}{l}\text { Kościół Katolicki- } \\
\text { wyrównanie }\end{array}$ & & & & & \\
\hline $\begin{array}{l}\text { Włoska Unia Chrześ- } \\
\text { cijańskich Kościołów } \\
\text { Adwentystów Dnia } \\
\text { Siódmego }\end{array}$ & 23.292 & 0,06 & 0,13 & & \\
\hline $\begin{array}{l}\text { Zgromadzenia Boże } \\
\text { we Włoszech }\end{array}$ & 42.074 & 0,10 & 0,24 & & \\
\hline Stół Waldensów & 547.519 & 1,34 & 3,16 & & \\
\hline $\begin{array}{l}\text { Kościół } \\
\text { Ewangelicko-Luterań- } \\
\text { ski we Włoszech }\end{array}$ & 29.295 & 0,07 & 0,17 & & \\
\hline $\begin{array}{l}\text { Związek Włoskich } \\
\text { Gmin Żydowskich }\end{array}$ & 59.089 & 0,14 & 0,34 & & \\
\hline $\begin{array}{l}\text { Chrześcijańska Unia } \\
\text { Ewangelicko-Bapty- } \\
\text { styczna Włoch }\end{array}$ & 16.560 & 0,04 & 0,10 & & \\
\hline $\begin{array}{l}\text { Kościół Apostolski } \\
\text { we Włoszech }\end{array}$ & 9.578 & 0,02 & 0,06 & & \\
\hline $\begin{array}{l}\text { Święta Archidiecezja } \\
\text { Prawosławna Włoch } \\
\text { i Egzarchat dla Euro- } \\
\text { py Południowej }\end{array}$ & 35.702 & 0,09 & 0,21 & & \\
\hline Włoska Unia Buddyjska & 164.934 & 0,40 & 0,95 & & \\
\hline $\begin{array}{l}\text { Włoska Unia Hin- } \\
\text { duistyczna Sanatana } \\
\text { Dharma Samgha }\end{array}$ & 20.626 & 0,05 & 0,12 & & \\
\hline $\begin{array}{l}\text { Włoski Instytut Bud- } \\
\text { dyjski Soka Gakkai }\end{array}$ & 52.777 & 0,13 & 0,30 & & \\
\hline OGÓŁEM & 17.340 .826 & 42 & 100 & & \\
\hline
\end{tabular}

Kwoty określone są w euro.

* W odniesieniu do państwa w tabeli wskazano dochody potencjalnie należne w oparciu o decyzje podatników, to znaczy bez uwzględnienia pomniejszeń przewidzianych w obowiąujacych przepisach.

*** W odniesieniu do tego roku stwierdzono a posteriori pewne błędy popetnione przez jedno z Centrów Poradnictwa Podatkowego (Caf) we wskazaniach, mających znaczenie krajowe, które faworyzowaty Kościót Ewangelicko-Luterański (prawidłowy odsetek wynosi 0,18\%, a nie 0,36\%), z niekorzyścią dla Ewangelickiego Kościoła Waldensów (prawidlowy odsetek wynosi 2,82\%, a nie 2,64\%), odnosząc się do kwoty 2.228.422,70 euro. Procedura wyrównania kwot jest w toku. 


\begin{tabular}{|c|c|c|c|c|c|}
\hline \multirow[b]{2}{*}{ Beneficjenci } & \multicolumn{5}{|c|}{ Dochody z 2017 r. rozdzielane w 2021 r.*** } \\
\hline & $\begin{array}{l}\text { Ważne } \\
\text { wybory } \\
\text { wyraźne }\end{array}$ & $\begin{array}{c}\text { \% wyborów } \\
\text { w stosunku } \\
\text { do liczby } \\
\text { podatników }\end{array}$ & $\mid \begin{array}{c}\% \text { w stosunku } \\
\text { do ogólnej } \\
\text { liczby } \\
\text { wyborów }\end{array}$ & Kwoty & $\begin{array}{c}\% \\
\text { wpływów }\end{array}$ \\
\hline Państwo* & 2.692 .480 & 6,53 & 15,65 & & \\
\hline $\begin{array}{l}\text { Kościół Katolicki - } \\
\text { zaliczka }\end{array}$ & 13.508 .714 & 32,78 & 78,51 & & \\
\hline $\begin{array}{l}\text { Kościół Katolicki - } \\
\text { wyrównanie }\end{array}$ & & & & & \\
\hline $\begin{array}{l}\text { Włoska Unia Chrześ- } \\
\text { cijańskich Kościołów } \\
\text { Adwentystów Dnia } \\
\text { Siódmego }\end{array}$ & 22.541 & 0,05 & 0,13 & & \\
\hline $\begin{array}{l}\text { Zgromadzenia Boże } \\
\text { we Włoszech }\end{array}$ & 41.611 & 0,10 & 0,24 & & \\
\hline Stół Waldensów & 538.136 & 1,31 & 3,13 & & \\
\hline $\begin{array}{l}\text { Kościół } \\
\text { Ewangelicko-Luterań- } \\
\text { ski we Włoszech }\end{array}$ & 29.079 & 0,07 & 0,17 & & \\
\hline $\begin{array}{l}\text { Związek Włoskich } \\
\text { Gmin Żydowskich }\end{array}$ & 57.960 & 0,14 & 0,34 & & \\
\hline $\begin{array}{l}\text { Chrześcijańska Unia } \\
\text { Ewangelicko-Bapty- } \\
\text { styczna Włoch }\end{array}$ & 17.851 & 0,04 & 0,10 & & \\
\hline $\begin{array}{l}\text { Kościół Apostolski } \\
\text { we Włoszech }\end{array}$ & 9.386 & 0,02 & 0,05 & & \\
\hline $\begin{array}{l}\text { Święta Archidiecezja } \\
\text { Prawosławna Włoch } \\
\text { i Egzarchat dla Euro- } \\
\text { py Południowej }\end{array}$ & 38.212 & 0,09 & 0,22 & & \\
\hline Włoska Unia Buddyjska & 164.982 & 0,40 & 0,96 & & \\
\hline $\begin{array}{l}\text { Włoska Unia Hin- } \\
\text { duistyczna Sanatana } \\
\text { Dharma Samgha }\end{array}$ & 22.971 & 0,06 & 0,13 & & \\
\hline $\begin{array}{l}\text { Włoski Instytut Bud- } \\
\text { dyjski Soka Gakkai }\end{array}$ & 63.228 & 0,15 & 0,37 & & \\
\hline OGÓŁEM & 17.207 .151 & 42 & 100 & & \\
\hline
\end{tabular}

Kwoty określone są w euro.

* W odniesieniu do państwa w tabeli wskazano dochody potencjalnie należne w oparciu o decyzje podatników, to znaczy bez uwzględnienia pomniejszeń przewidzianych w obowiąujacych przepisach.

*** W odniesieniu do tego roku stwierdzono a posteriori pewne błędy popetnione przez jedno z Centrów Poradnictwa Podatkowego (Caf) we wskazaniach, mających znaczenie krajowe, które faworyzowaty Kościót Ewangelicko-Luterański (prawidłowy odsetek wynosi 0,18\%, a nie 0,36\%), z niekorzyścią dla Ewangelickiego Kościoła Waldensów (prawidłowy odsetek wynosi 2,82\%, a nie 2,64\%), odnosząc się do kwoty 2.228.422,70 euro. Procedura wyrównania kwot jest $w$ toku. 


\section{ZAŁĄCZNIK B}

Procentowa część otto per mille, która mogłaby być przyznana na podstawie wyborów wyraźnych, porównana z tą, która została faktyczne przydzielona

\begin{tabular}{|c|c|c|c|c|c|c|c|c|c|c|c|c|}
\hline Beneficjent & 1990 & 1991 & 1992 & 1993 & 1994 & 1995 & 1996 & 1997 & 1998 & 1999 & 2000 & 2001 \\
\hline \multirow{2}{*}{ Państwo } & 11,97 & 8,84 & 6,06 & 5,12 & 5,98 & 5,71 & 6,42 & 5,94 & 5,02 & 4,04 & 3,84 & 3,94 \\
\hline & 22,31 & 16,68 & 13,00 & 12,42 & 14,08 & 13,87 & 14,43 & 14,52 & 13,36 & 11,04 & 10,35 & 10,28 \\
\hline \multirow{2}{*}{$\begin{array}{l}\text { Kościół } \\
\text { Katolicki }\end{array}$} & 40,86 & 43,15 & 39,62 & 35,36 & 35,48 & 34,45 & 36,75 & 33,36 & 31,35 & 31,67 & 32,33 & 33,43 \\
\hline & 76,17 & 81,43 & 84,94 & 85,70 & 83,60 & 83,68 & 82,56 & 81,58 & 83,36 & 86,58 & 87,17 & 87,25 \\
\hline \multirow{2}{*}{$\begin{array}{l}\text { Włoska Unia } \\
\text { Chrześcijańskich } \\
\text { Kościołów } \\
\text { Adwentystów } \\
\text { Dnia Siódmego }\end{array}$} & 0,51 & 0,69 & 0,73 & 0,56 & 0,38 & 0,41 & 0,35 & 0,26 & 0,16 & 0,12 & 0,11 & 0,10 \\
\hline & 0,95 & 1,31 & 1,57 & 1,35 & 0,89 & 1,00 & 0,80 & 0,64 & 0,44 & 0,32 & 0,28 & 0,27 \\
\hline \multirow{2}{*}{$\begin{array}{l}\text { Zgromadzenia } \\
\text { Boże we } \\
\text { Włoszech }\end{array}$} & 0,30 & 0,31 & 0,23 & 0,22 & 0,14 & 0,15 & 0,18 & 0,18 & 0,19 & 0,08 & 0,08 & 0,08 \\
\hline & 0,57 & 0,58 & 0,49 & 0,53 & 0,33 & 0,36 & 0,41 & 0,44 & 0,50 & 0,21 & 0,21 & 0,20 \\
\hline \multirow{2}{*}{$\begin{array}{l}\text { Stół } \\
\text { Waldensów }\end{array}$} & - & - & - & - & 0,47 & 0,45 & 0,66 & 0,65 & 0,50 & 0,40 & 0,45 & 0,49 \\
\hline & - & - & - & - & 1,10 & 1,09 & 1,48 & 1,59 & 1,33 & 1,10 & 1,21 & 1,27 \\
\hline \multirow{2}{*}{$\begin{array}{l}\text { Kościół } \\
\text { Ewangelicko- } \\
\text { Luterański } \\
\text { we Włoszech }\end{array}$} & - & - & - & - & - & - & 0,14 & 0,25 & 0,14 & 0,11 & 0,12 & 0,12 \\
\hline & - & - & - & - & - & - & 0,32 & 0,60 & 0,38 & 0,31 & 0,32 & 0,31 \\
\hline \multirow{2}{*}{$\begin{array}{l}\text { Związek } \\
\text { Włoskich Gmin } \\
\text { Żydowskich }\end{array}$} & - & - & - & - & - & - & - & 0,26 & 0,24 & 0,16 & 0,17 & 0,16 \\
\hline & - & - & - & - & - & - & - & 0,63 & 0,63 & 0,44 & 0,46 & 0,42 \\
\hline
\end{tabular}




\section{FINANCING OF RELIGIOUS ORGANIZATIONS IN THE REPUBLIC OF ITALY: MANAGEMENT OF TAX ASSIGNMENT (OTTO PER MILLE) FUNDS AS THE SUBJECT OF THE COURT OF AUDITORS' CRITICISM}

\section{Summary}

The present paper focuses on one of the main features of the system of financing of churches and other religious organizations in Italy, namely, the assignment of $0.8 \%$ of personal income tax (the so-called otto per mille). In the years 2014-2018, the Italian Court of Auditors (Corte dei Conti) passed four resolutions addressing this issue. The reports approved in this way contain a number of remarks concerning the management of funds coming from this source. The first part of the paper discusses the institution of otto per mille as a point of reference in numerous debates on modern ways of funding religious organizations. Next, the paper details the criticisms raised in the reports and presents the official positions of religious organizations, including that of the Catholic Church. In the conclusion, an attempt is made to critically evaluate both the views expressed by the Italian Court of Auditors, the commentaries pertaining to these views and initiatives inspired by them.

Key words: tax assigment; otto per mille; Italy; churches and other religious organizations; personal income tax 
